\title{
Bir Sağlık Arama Davranıșı Olarak Sosyal Medya Kullanımı: İzolasyon, Karantina ve Sosyal Mesafe Tedbirlerinde Facebook'ta Covid-19 İçerikli Sosyal Medya Paylaşımlarının Görünümüi
}

\section{Use of Social Media as a Health Seeking Behaviour: Looking Into Covid-19 Related Social Media Posts on Facebook During The Measures of Isolation, Lockdown and Social Distance}

\author{
Emine SAHIN ${ }^{1} \odot$, Ferihan AYAZ $^{2} \odot$
}

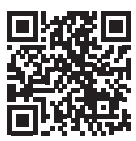

'Assoc. Prof. Dr., Gaziantep University, Faculty of Communication, Department of Advertising, Gaziantep, Turkey

${ }^{2}$ Asst. Prof. Dr., Gaziantep University, Faculty of Communication, Department of Journalism, Gaziantep, Turkey

ORCID: E.Ş. 0000-0002-7269-0923;

F.A. 0000-0003-3277-5188

\section{Sorumlu yazar/Corresponding author: Emine Şahin, Gaziantep University, Faculty of Communication, Department of Advertising, Gaziantep, Turkey \\ E-posta/E-mail: \\ emines@gantep.edu.tr}

\section{Geliş tarihi/Received: 15.01.2021}

Revizyon talebi/Revision Requested: 19.01.2021 Son revizyon teslimi/Last revision received: 06.06.2021

Kabul tarihi/Accepted: 07.06.2021

Atıf/Citation: Şahin, E., \& Ayaz, F. (2021). Bir sağlık arama davranışı olarak sosyal medya kullanımı: İzolasyon, karantina ve sosyal mesafe tedbirlerinde Facebook'ta Covid-19 içerikli sosyal medya paylaşımlarının görünümü. Connectist: Istanbul University Journal of Communication Sciences, 60, 185-215.

https://doi.org/10.26650/CONNECTIST2021-862042 öz

Çalışmanın temel amacı Koronavirüs (Covid-19) sürecinde izolasyon, karantina ve sosyal mesafe şartlarında sağlık arama davranışı gösteren kişilerin, Facebook'un Covid-19 konulu gruplarında yaptıkları paylaşım ve yorumlarına sağlık arayışının nasıl yansıdığını ortaya koymaktır. Bu kapsamda Facebook'ta Corona virüsü (Covid-19) Bilgi Paylaşımı ve Yardımlaşma-Türkiye, Covid-19 Bilgi Paylaşım Platformu ve Covid-19 Yakalananlar Bilgi ve Birlik Platformu Türkiye sosyal medya grupları araştırmaya dâhil edilmiştir. Gruplardan 07 Ekim 2020 ve 07 Ocak 2021 tarihleri arasından basit rastlantısal örneklem tekniğiyle seçilen 600 paylaşım ve yorum betimsel yöntem ile içerik analizi tekniği kullanılarak incelenmiştir. Alanyazın taramasına dayanarak araştırmacılarca oluşturulan kodlama cetveli ile (güvenilirlik \%92,95 olarak) paylaşım ve yorumlar analiz edilmiş analiz sonucunda katılımcıların ağırıkı olarak iyi dilekler/teselli/dua/teşekkür $(\% 35,3)$ içeren paylaşım ve yorumlarda bulunduğu, Covid-19'un deneyim/tedavi süreci hakkında soru sorarak $(\% 41,3)$ diğer katılımcılardan bilgi talep ettiği belirlenmiştir. Elde edilen bulgulara göre paylaşım ve yorumlar cinsiyete göre farklılık göstermektedir, bulguların \%86,3'ünü yorumlar oluşturmaktadır. Çalışmanın sonunda Python programlama dili kullanılarak kelime bulutu oluşturulmuş paylaşım ve yorumların genel dağııımı belirlenmiştir. Çalışmada bu anlamda sosyal ağların, sağlık bilgisi arama ve korku paradoksu, gizlilik, düşük güven düzeyi gibi sorunsallarına rağmen duygusal destek ve bilgiye ulaşmada bir kaynak olarak kullanıldığı ortaya konmaktadır.

Anahtar Kelimeler: Sağlık arama davranışı, sosyal medya, Covid-19, Facebook, içerik 


\begin{abstract}
The study aims to demonstrate how health seeking is reflected in users' posts and comments in Covid-19-themed groups on Facebook as a social media platform, under the conditions of isolation, lockdown and social distance in the Covid-19 process. In this scope, the study examined Facebook groups: The Coronavirus (Covid-19) Information Exchange and Cooperation-Turkey, The Covid-19 Information Sharing Platform, and The Information and Solidarity Platform for Those Diagnosed with Covid-19 Turkey. 600 posts and comments were selected using the random sampling technique and analysed using descriptive method content analysis technique. This was conducted through a coding layout developed by the researchers based on field research (92.95\% reliability)
\end{abstract}

and showed that the participants mainly shared emotional support posts and comments that included good wishes/ consolation/prayer/thanks (35.3\%) and asked questions about the Covid-19 experience/treatment (41.3\%) process for information. The posts differed by gender and $86.3 \%$ of them received comments. Finally, a word cloud was created using Python, and the overall distribution of the posts and comments was determined. The study demonstrates that digital channels and social networks are used for emotional support and as a source in seeking health information despite having problems such as causing the paradox of fear, issues of confidentiality, and a low confidence level.

Keywords: Health seeking behaviour, social media, Covid-19, Facebook, content

\section{EXTENDED ABSTRACT}

Persons who are diagnosed or whose family members are diagnosed with Covid-19 try to seek information about symptoms, diagnosis, protection methods, resources related to treatment, and possible results. Also, social networks created on social media by patients, patient relatives and civil society organisations contribute to interaction between members, good health information management (Cangelosi, Kim, Ranelli, \& Griffin, 2018) funding of organisations, fundraising and awareness raising (Thoren, Metze, Bührer, \& Garten, 2013, p. 534; Öztürk \& Öymen, 2014, p. 114; Mamun, İbrahim, \& Turin, 2015). In social networks where a sense of belonging to the groups has been developed, it is sometimes sufficient for the users of the network to just share sentimental posts and feel relieved without pursuing any specific goal (DeSouza \& Jyoti Dutta, 2008; Nahm, Resnick, DeGrezia, \& Brotemarkle, 2009; Mitchell \& Grieve, 2020). Since Facebook is a highly interactive social network that provides information and emotional support, the researchers examined it within the scope of this study.

This study aims to reveal how health seeking behaviour is reflected in the users' posts and comments in Covid-19 themed groups on Facebook as a social media platform, under the conditions of isolation, lockdown and social distance in the Covid-19 pandemic process. Within the scope of this aim, the study by using the descriptive method content analysis technique, examined the posts and comments on 3 actively-used Facebook groups: The Covid-19 Information Exchange and Cooperation-Turkey, The Covid-19 
Information Sharing Platform, and The Information and Solidarity Platform for Those Diagnosed with Covid-19 Turkey. The reliability results obtained during the pre-test concerning the coding layout developed by the researchers based on field research showed that the coding layout used was highly reliable ( $92.95 \%$ reliability) for this research (Table 1). 300, 200 and 100 posts and comments were selected from the Facebook groups between 07.10.2020 and 07.01.2021 using the simple random sampling technique. The posts and comments were evaluated in 15 primary and 59 secondary categories such as posts and comments time, gender, quality, theme, information sharing, question type, complaints, the medicine used, number of likes, emoji, comment and number of comments, photographs, hashtag, and mention of trying to seek answers for the research questions (Appendix 2).

The findings showed that many posts and comments (35.3\%) included "good wishes/ consolation/prayer/thanks" (Figure 1). These were followed by posts and comments related to notifying the situation/sharing experience (25.3\%). Another significant theme was "asking questions related to health" $(15 \%)$. Members seek to find ways to overcome a newly-confronted health problem by asking questions to each other. The other types of content include "warning/advice" (7\%), "information sharing" (6.8\%), "Covid-19 complaints" (6\%), and "grievance/rebellion/reproach" (2.3\%). The posts also included "advertisement of caretaking services and herbal products" (2\%). The most common type of information was related to "symptoms" $(20.1 \%)$, and the most common type of question was related to "experience/treatment" (41.3\%).

The most common type of complaint on Facebook groups was "body aches" (15.9\%). This is followed by "loss of taste/smell" (11.5\%), "coughing" (9.2\%), "shortness of breath" (7.6\%) and "fever" (6.8\%). The medicines that are used or recommended are mainly the "medicine specific to Covid-19 recommended by medical specialists" (Figure 5). Posts and comments were mostly shared by women (\%54) and $86.3 \%$ of them received comments. At the end of the study, a word cloud was created using Python, and the overall content distribution was determined (Figure 6).

On the other hand, the increase in health-related concerns as a result of repeated health information seeking on digital channels has caused a paradox called cyberchondria (Karaer-Karapıçak, Aslan, \& Utku, 2012; Altındiş, İnci, Aslan, \& Altindiş, 2018). Despite their negative aspects, social networks should be considered as an alternative communication channel that provides the information and emotional support needed. 


\section{GíRiş}

Dünyayı etkisi altına alan Covid-19 pandemisi Çin'in Hubei eyaleti, Vuhan şehrinde, 31 Aralık 2019'da ilk vakanın görülmesi ile ortaya çıkmış ancak Dünya Sağlık Örgütü tarafından 11 Şubat 2020 itibariyle doğrulanmıştır (Qiu et al., 2020). Türkiye'de Covid-19 pandemisi 11 Mart tarihinde resmî olarak ilan edilmiştir (Türkiye Cumhuriyeti Sağlık Bakanlığı, 2020). Bu dönemde uygulanan kısıtlamalar Türkiye'de zaman zaman vaka ve ölüm sayılarında azalmayı sağlasa da 2020 Ağustos ayının son günlerinde yeniden artış yaşanmıştır. Türkiye'de 13 Ocak 2021 itibarılya Covid-19'dan etkilenen kişi sayısı 1 milyon 355 bin 839 ve ölü sayısı 23 bin 325'tir (Covid-19 Hasta Tablosu, 2021). Dünya genelinde ise 90 milyon 335 bin 8 kişi Covid-19'dan etkilenmiştir, ölü sayısı ise 1 milyon 954 bin 338 kişidir (Word Health Organization, 2021). Böylece Covid-19 pandemisi Şubat 2003'te Singapur'da başlayan SARS'tan daha büyük bir felaket olarak tarihe geçmektedir.

Mart 2020'den bugüne ülke genelinde sokağa çıkma kısıtlamasının olduğu günlerle, hastalık belirtileri gösteren, kendilerine ya da yakınlarına hastalık teşhisi konan kişilerin karantinada kaldığı günler evde kalınan süreyi uzatmıştır. İzolasyon nedeniyle gündelik hayatta yapılan alışkanlıklara, sosyal ve kültürel faaliyetlere bir anda ara verilmiştir. Diğer taraftan Covid-19'un kontrol altına alınıp alınamayacağı, karantinada kalma süresinin ne zamana kadar süreceği, yayılım, önlem ve tedavi hakkında net bilginin olmadığı bu kritik dönemde insanlar belirsizlik yaşamıştır. Bu dönemde izolasyon, karantina ve sosyal mesafe tedbirlerinin, aniden gelişen pandeminin neden olduğu belirsizliğin ve korkunun etkileri psikometrik ve davranış saptamaya yönelik araştırmalarla incelenmiştir.

Covid-19 pandemisinde sağlık davranışı gösterme ile bağlantılı olarak, korku veya kaygı seviyesinin kurallara uyma eğilimini arttırdığı belirlenmiştir (Harper, Satchell, Fido, \& Latzman, 2020). Amerika'da psikolojik etkilenme düzeyi yüksek olan ve öz kontrol sahibi kişiler Covid-19 salgınına özel sağlık kurallarına, psikolojik etkilenme düzeyi düşük olanlara göre daha fazla uyum sağlamıştır (Zitek \& Schlund, 2020). Bu dönemde insanlar hastalıktan korunma, teşhis ve tedavi yöntemleri içeren mesajların paylaşıldığı iletişim kanallarına önem vermekte ve belirtilen önlemleri uygulamakta daha fazla istekli davranmaktadır.

Covid-19 korkusu her zaman sağlık davranışı geliştirmeye yönelik olumlu davranışa yol açmazken artan ruh sağlığı sorunları ile ilişkilendirilmiştir. Salgın tehlikesinin neden 
olduğu "Covid-19 korkusu" (Ahorsu et al., 2020) nedeniyle depresyon, kaygı, stres gibi psikolojik problemleri konu edinen araştırmaların sayısı artmıştır (Dsouza, Quadros, Hyderabadwala, \& Mamun, 2020; Qiu et al., 2020; Wang et al., 2020). Herkes için korkuyla başlayan ruhsal bozukluk bazıları için intiharla sonuçlanmaktadır (Dsouza et al., 2020; Griffiths \& Mamun, 2020). Diğer taraftan izolasyon, karantina ve sosyal mesafenin uygulandığı zaman kapsamında ortaya çıkan olumsuz psikolojik koşulların bir sonucu olarak çevrim içi oyun (Balhara et al., 2020; King, Delfabbro, Billieux, \& Potenza, 2020), internet (Kircaburun et al., 2020; Soraci et al., 2020), egzersiz (de la Vega et al., 2020), sosyal medya (Fernandes et al., 2020) bağımlılığındaki artış, bireyin içinde bulunduğu durumla başa çıkma davranışı olarak görülmektedir.

Bireyler hastalığın yayılma hızı, enfekte olma koşulları, belirtileri, tedavi süreci hakkında çok fazla bilgi sahibi değilken algılanan risk çok yüksektir (Baumgartner \& Hartmann, 2011; Karaer-Karapıçak et al., 2012; Altındiş et al., 2018; Li, Wang, Lin, \& Hajli, 2018; Wang et al., 2020). Pandemi döneminde de Covid-19'a yakalanma korkusu ve seyrindeki belirsizlik kendisi ve yakınları hastalık riski taşıyan ya da hastalık kapan kişilerde etkili olmaktadır (Duman, 2020, p. 424; Satici, Saricali, Satici, \& Griffiths, 2020). Bu dönemde artan korku ve stres; depresyon ve anksiyete gibi ruhsal sorunlara neden olmakta, insanları mutsuz etmektedir. Çin'de yapılan sınırlı çalışmada hastalıkla ilgili birçok konuda belirsizliğin yaşandığı bu dönemde kadınların daha yüksek stres, kaygı ve depresyon seviyelerine sahip olduğu ortaya konmuştur (Wang et al., 2020; Qiu et al., 2020, p. 2). İnsanlar en çok hastalığın bulaşmasından korkmaktadır (Fernandes et al., 2020, p. 61). Bu süreçte hastalığın bulaşma yolu, ilaçların/aşıların bulunabilirliği ve etkinliği, seyahat tavsiyeleri gibi bilgilerin yanı sıra kronik hastalıkları olan kişiler için ayrıntılı bilgi ve düzenli güncelleme talep edilmiştir (Wang et al., 2020).

Insanlardaki sağlık bilgisi arama davranışı, hastalıkla ilgili belirsizliği azaltma, koşulların düzeleceğine yönelik umutlanma ve böylece oluşan krizin psikolojik etkilerinden kurtulmayı amaçlamaktadır (Brashers, Goldsmith, \& Hsieh, 2002). Ancak bu dönemde bilgilerin doğruluğu, hangi iletişim kanalından ne sıklıkla, ne zaman verildiği ve sunumu önem kazanmaktadır. Covid-19 pandemisinde sağlık bilgisi aramada internet tabanlı uygulamaların kullanımı, kendi ve yakınlarının sağlığını kaybetme korkusu ve endişesi yaşayanlar için çok önemli rol oynamıştır. Çin'de internetin $(\% 93,5)$ bilgiye erişimde birincil araç olduğu belirlenmiştir (Wang et al., 2020). Ticari kuruluşlar müşterilerinin mevcut durum hakkında güvenilir bilgi paylaşımını sağlamak ve yararlı veri toplamak için forumlar oluşturmuştur (Ahani \& Nilahsi, 2020, p. 21). Böylece Covid-19 salgını gibi 
beklenmedik sağlık krizinde müşterilerin ve işletmelerin daha iyi karar vermesine yardımcı olmak için sosyal platformlar üzerinden bireyler yönlendirilmiştir. Covid-19 sürecinde resmi otoriteler ve kanaat önderleri Twitter kişisel sayfalarında halkı rahatlatmaya, korku düzeyini düşürmeye yönelik mesajlar paylaşmıştır (Harper et al., as cited in Murpy, 2020; Yum, 2020, p. 1645). Covid-19 döneminde sosyal medyada yayınlanan mesajların etkisi incelendiğinde hijyen, sosyal mesafe, maske kullanımı gibi içeriklerin zorunluluktan çok görev ve sorumluluk bilinci aşılamaya yönelik (deontolojik) mesajlarla aktarıldığında daha ikna edici olduğu belirlenmiştir (Everett, Colombatto, Chituc, Brady, \& Crockett, 2020, p. 11).

Türkiye'de yapılan Covid-19 konulu çalışmaların pandeminin psikolojik etkileri (Duman, 2020; Kircaburun et al., 2020; Saricali, Satici, Satici, Gocet-Tekin, \& Griffiths, 2020; Satici et al., 2020), Sağlık Bakanlığı́nın pandemi politikası (Demirbilek, Pehlivantürk, Özgüler, \& Alp-Meşe, 2020), pandemide teknoloji kullanımı (Gökler \& Turan, 2020) ve sosyal medya kullanıcılarının Covid-19 algısı (Öngel, Tarlı, \& Bozkurt, 2020) gibi konularda yapıldığı belirlenmiştir. Covid-19 pandemi döneminde sosyal medyada kendisi ve yakınları hastalığa yakalanmış ya da yakalanma riski taşıyan kişilerce bir sağlık arama davranışı olarak ne tür bilgilerin arandığı ve ne tür bilgilerin fizyolojik olarak bulaştan etkilenen ya da etkilenme intimali olan diğer insanların kullanımına sunulduğuna dair bir araştırmaya rastlanmamıştır. Ancak sosyal medya toplumun büyük kesimi için hakkında çok az şeyin bilindiği pandemi hakkında çok fazla bilgiye kolaylıkla ulaşılan büyük veri özelliği taşımaktadır. Özellikle izolasyon, karantina ve sosyal mesafe döneminde insanlar dışarı çıkamamakta, genel sağlık sorunları için bile sağlık uzmanıyla görüşmeyi riskli görmektedir. Bu dönemde sivil toplum kuruluşları ve özel kişilerce oluşturulan bilgi, duygu ve deneyimlerin paylaşıldığı, uzamdan, zamandan bağımsız, etkileşime açık ve geniş kitleleri saran sosyal medya grupları bilgiye erişmede, belirsizliği azaltmada kurtarıcı olarak görülmektedir. Bu anlamda çalışma kapsamında pandemi sürecinde Facebook sosyal ağında kurulan Covid-19 konulu üç grup belirlenmiş, gruplarda yapılan paylaşımlarla paylaşımlara yapılan yorumların içerikleri nicel içerik analizi yaklaşımıyla incelenmiştir. Böylece katılımcıların sosyal medya gruplarında Covid-19'a dair ne tür bilgiler aradığı ya da diğer kullanıcılara ne tür bilgi ve destek sağladığı paylaşım ve yorumlar üzerinden belirlenmiştir. Çalışmada bir anlamda, Covid-19 pandemisinde sağlık aramada sosyal medyanın kullanım nedenleri kullanım pratiklerine dayanarak ortaya konmuştur. 


\section{Covid-19 Döneminde İnternet ve Sosyal Medya Kullanımı}

Dijital ağlar sosyal işlevselliği bakımından gerçek dünyadaki topluluklarla benzerlik taşımaktadır. Gerçek hayatta topluluklar sosyalleşme, destek sağlama, bilgiye erişim, aidiyet hissi ve kişilerarası bağlardan oluşan ağlar olarak ifade edilmektedir (Wellman, 2001, p. 127). Oluşturulan bağlar internet teknolojisi aracılığı ile binlerce kişinin katılımıyla genişletilmektedir. Böylece topluluğun geleneksel tanımı da değişerek kişisel bilgisayarlardan dışa vurumcu sosyal grup formlarının ortaya çıkmasına neden olmaktadır (Bauman, 2016, p. 173). Sanal toplulukları, katılımcıların demografik özellikleri, örgütsel bağlamı, üyelerin sosyo-kültürel özelliklerine göre gruplandırmak mümkünken (Dube, Bourhis, \& Jacob, 2006, p. 75) topluluğun üyelerini birbirine bağlayan konu/sorun bütünlüğü, bireylerin dijital katılıma bağımlılık derecesi ve ağın fonksiyonel oluşu belirleyici olmaktadır. Çok farklı demografik özelliklere sahip katılımcılar kimlik, sosyalleşme ve aidiyet duygusu içinde benzer beklentileri nedeniyle sosyal ağlarda bir araya gelmektedir. Dijital sosyal ağlarda sağlık problemine çözüm aramak bu alanlarda kurulan sosyal medya uygulamalarına da farklı işlevsellik kazandırmaktadır.

Küresel Covid-19 salgınında izolasyon, karantina ve sokağa çıkma yasağının olduğu günlerde internet ve sosyal ağların kullanımı evde gündelik hayatını devam ettirmek zorunda kalan milyonlarca insan için hayati önem taşımıştır. "We are Social" internet sitesinin araştırmasında katılımcıların \%83'ü internetin Covid-19 ile başa çıkmada kendilerine yardım ettiğini belirtmiştir (2020). Pandemi nedeniyle sokağa çıkma kısıtlamalarının, izolasyon ve sosyal mesafe tedbirlerinin başladığı Mart ayında internet tabanlı Netflix ve BluTV gibi dijital kanalların \%50 daha fazla izlendiği belirlenmiştir (Deloitte, 2020, p. 4). Sosyal medya kullanım ölçümleri incelendiğinde Covid-19 pandemisinde kullanıcı sayısının geçen yıla oranla \%10 arttığı ve Temmuz 2020'nin başında toplam 3,96 milyara ulaştığı ortaya konmuştur (toplam nüfusun \%51'i). Bu oran neredeyse 346 milyon yeni kullanıcıya denk gelmektedir (We Are Social, 2020). Pandemi sürecinde dünya genelinde 2.6 milyar kullanıcısı ile Facebook ilk (\%46), 2 milyar kullanıcısı ile YouTube ikinci ve 2 milyar kullanıc ile WhatsApp üçüncü sıradadır (2020). Sosyal medyada en çok paylaşım Japonya, ABD ve Güney Kore'den yapılmış, Türkiye ise \%2.2 düzeyi ile 11. sırada yer almıştır, Türkiye'de ilk vakanın açıklandığı 11 Mart tarihinde, 747 bin 862 paylaşım yapılmıştır (The Brand Age, 2020). Görünen o ki bireyler bir taraftan rutin sosyal ve kültürel aktivitelerini gerçek dünyadan dijital boyuta taşımış, bir taraftan da güncel bilgiye ulaşmada dijital medyayı önemli bir kaynak olarak kullanmayı tercih etmiştir. 


\section{Sosyal Medyada Sağlık Arama Davranışı}

Bireylerin kendileri ya da yakınları, sağlıklarını kaybetme riski ile karşılaştıklarında hastalıkla ilgili tanı, teşhis, tedavi ve tedavinin olası sonuçları hakkında destek alabilecekleri kaynaklarda bilgi arama çabasına girmektedir. Bu çaba sağlık bilgisi arama davranışı (Health Information Seeking Behavior - HISB) olarak bireylerin sağlıkları, riskleri, hastalıkları ve sağlığı koruyucu davranışlar hakkında bilgi arama yollarını ifade etmektedir (Lambert \& Loiselle, 2007, p. 1006). İnternetin sağlık alanında bilgiye erişimde aktif olarak kullanılmaya başlamasıyla online sağlık bilgisi arama, internette sağlık arama davranışı olarak kavramsallaştırılmıştır (Gallagher \& Doherty, 2009; Baumgartner \& Hartmann, 2011; Kim, Shah, Namkoong, McTavish, \& Gustafson, 2013; Kıraç, 2019; Dau et al., 2020). Kavramın teorik çerçevesi algı, tutum ve davranış temelli modellere dayandırılarak (Li et al., 2018; You (Ryu) \& Cho, 2020; Mitchell \& Grieve, 2020; Alsisi et al., 2020) hastaların sağlık bilgisi, sağlıklı yaşam bilinci kazanımı ve bunların davranışa yansıması kapsamında şekillenmektedir. Sağlık arama davranışı düzeyini ve şeklini bireylerin yaşı, cinsiyeti, mesleği, gelir ve eğitim düzeyi gibi değişkenlerin (Gallagher \& Doherty, 2009, p. 104; Kim, 2015, p. 229; Jacobs, Amuta, Jeon, \& Alvares, 2017, p. 5; Das, Angeli, Krumeich, \& van Schayck, 2018) yanı sıra sağlık algısı (Ağaçdiken-Alkan, Özdelikara, \& Boğa, 2017), sağlık okuryazarlığı, öz yeterlik ve sağlık bilgisi oryantasyonu (Mitchell \& Grieve, 2020; You (Ryu) \& Cho, 2020), sağlık kaygısı ve algılanan risk (Baumgartner \& Hartmann, 2011; Karaer-Karapıçak et al., 2012; Li et al., 2018) gibi faktörler belirlemektedir.

Sağlık arama davranışı, sosyal çevre ve geleneksel iletişim araçlarının yanı sıra web siteleri ve çevrim içi uygulamalar kullanılarak yapılmaktadır. Araştırmalarda internet tabanlı uygulamalarda sağlık arama davranışının arttığı belirlenmiştir (Schwartz et al., 2006, p. 42; Kim, 2015, p. 98; Jacobs et al., 2017, p. 6). Bireylerin \%77'si sağlık arama davranışına Google, Bing veya Yahoo gibi bir arama motorundan kelime aramayla başlamaktadır (Fox \& Duggan, 2013). Sağlık arama davranışında internet tabanlı uygulamaların kullanım amaçları arasında, hastalık belirtileri ve bulguları hakkında bilgi almak, ilaç ve tedavilerini araştırmak, hastalık sürecinde deneyimlerini başkalarıyla paylaşmak, aynı konuda farklı görüş ve bilgilere erişmek (Shuyler \& Knight, 2003; Kim et al., 2013; Altındiş et al., 2018; Dau et al., 2020) gibi rasyonel bilgi arayışı yer almaktadır.

Sosyal ağların direk mesajlaşma (DM) özelliği aracılığı ile sağlık uzmanları ile iletişime geçen kullanıcılar, randevu ayarlama ve hatırlatma, test sonuçlarını bildirme, reçete/ tahlil bildirimleri gibi daha spesifik konularda dahi sosyal medyayı kullanmak istemektedir 
(AlQarni, Yunus, \& Househ, 2016; Fisher \& Clayton, 2012). Sosyal medya grupları, grubun diğer üyeleri ile etkileşime girmeye olanak tanıyarak sağlık sorunlarının daha iyi anlaşılmasına ve sorun yönetimine katkı sağlamaktadır (Cangelosi et al., 2018). Bazı gruplar kuruluşlara fon sağlamak, bağış toplamak ve farkındalık yaratmak (Thoren et al., 2013, p. 534; Öztürk \& Öymen, 2014, p. 114; Mamun et al., 2015) amacıyla oluşturulmaktadır. Katıımcılar sağlıklı beslenme, zararlı madde kullanımı gibi konularda bilgilendirilmektedir (Taggart et al., 2015). Bu çevrim içi topluluklar hastalığın neden olduğu kaygı, korku gibi ruh sağlığı sorunlarıyla baş etmek amacıyla duygusal destek (Gallagher \& Doherty, 2009, p. 104; Nahm et al., 2009; Greene, Choudhry, Kilabuk, \& Shrank, 2011, p. 287; Li et al., 2018, p. 36; Mitchell \& Grieve, 2020) sağlama/bulma aracı olarak da kullanılmaktadır.

Sosyal medya kullanııları en çok kanserin çeşitli türleri (Hale, Pathipati, Zan, \& Jethwani, 2014; Bozkanat, 2018), kalp sağlığı (Öztürk \& Öymen, 2014), hipertansiyon (Mamun et al., 2015), diyabet (Zhang, He, \& Sang 2013; AlQarni et al., 2016), anemi (Hale, 2014), bedensel problemler (Nahm et al., 2009) gibi kalıcı ve kronik, AIDS/HIV (DeSouza \& Jyoti Dutta, 2008; Taggart et al., 2015) gibi bulaşıcı rahatsızlıkların yanı sıra erken doğum (Thoren et al., 2013), diyet ve sağlıklı beslenme (Cangelosi et al., 2018) gibi tematik gruplarda bir araya gelmektedir. Facebook ve Twitter'da en fazla meme kanseri, bağırsak kanseri ve diyabet grubu olduğu belirlenmiştir (de la Torre-Díez et al., 2012, p. 404; Hale et al., 2014). Sivil toplum kuruluşları, hasta ve hasta yakınlarının oluşturduğu sosyal medya gruplarında bilgi içerikli ve duygusal paylaşımlar, devam eden kronik sağlık sorunları olan bireylerin hastalıklarının ruhsal ve fiziksel iyiliği üzerindeki zararı etkilerini azaltmaktadır.

\section{AMAÇ VE YÖNTEM}

Sosyal medyada sağlık arama davranışının Facebook sosyal ağında kurulan gruplarda yapılan paylaşım ve yorumlara yansıması bu çalışmanın temel sorunsalıdır. Bu bağlamda çalışmanın amacı ve araştırma soruları belirlenmiş betimsel yöntem ile içerik analizi tekniği kullanılarak bulgulara ulaşıımıştır.

\section{Amaç}

Sağlık arama davranışı ile ilgili çalışmalar konunun sağlık aramada demografik özelliklere, kültürel farklııklara, kurulan sosyal ağların türüne, teknoloji kullanımı ve 
sağlık aramanın nedenlerine odaklanmaktadır. Bu çalışma tüm dünyayı etkisi altına alan ve büyük panik yaratan Covid-19 pandemisi ile sınırlandıııımıştır. Çalışmanın temel amacı sağlık arama davranışı gösteren kişilerin bir sosyal ağ olan Facebook'taki gruplarda Covid-19 konulu paylaşım ve yorumlara sağlık arayışının nasıl yansıdığını ortaya koymaktır. Sosyal medya, erişimi kolay, zaman ve uzamdan bağımsız, etkileşime açık olması gibi nedenlerle Covid-19 sürecinde de tercih edilmiştir. Diğer taraftan sosyal medyada, Covid-19 pandemisine ilişsin sağlık arama davranışının nedenleri, ne tür bilgilerin arandığı ve paylaşıldığı, bu bilgilerin kullanılıp kullanılmadığı ekseninde büyük veri toplanmakta ve depolanmaktadır. Çalışma sosyal medyada oluşan büyük veriden kesit sunması bağlamında hem özgün hem de önemlidir.

Çalışmanın amacı doğrultusunda şu sorulara cevap aranmıştır:

1. Covid-19 konulu sosyal medya gruplarında, talep edilen ya da diğer katılımcıların kullanımına sunulan bilgi ve desteğin niteliği bağlamında, sağlık arama davranışı paylaşımlara nasıl yansımaktadır?

2. Covid-19 konulu sosyal medya gruplarında, iletişim sürecini anlamlandırmaya katkı sağlayan, katılımcıların paylaşımlara yaptığı yorumların, beğenilerin, paylaşımlarda kullanılan fotoğraf, video, mention, hashtag, linklerin oranı, paylaşımlarda kullanılan emojilerin niteliği ve oranı ne düzeydedir?

3. Genel olarak Facebook gruplarının, Covid-19 pandemisi gibi aniden ve beklenmedik gelişen sağlık krizinde iletişim ortamı olarak kullanımı nasıl yorumlanabilir?

\section{Yöntem}

Çalışma kapsamında araştırma Covid-19 sürecinde Facebook grup paylaşımlarının analizi betimsel yöntem kullanılarak tasarlanmış ve araştırmada nicel içerik analizi tekniği kullanılmıştır. lletişim, sanat, edebiyat çalışmalarının çözümlenmesinde kullanılan içerik çözümlemesi yaklaşımının terminolojisine katkı sağlayan Krippendorff (2004, p. 18) içerik analizini "Metinlerden veya diğer anlamlı maddelerden kullanım bağlamlarına kadar tekrarlanabilir ve geçerli çıkarımlar yapmak için bir araştırma tekniği" olarak tanımlamaktadır. Bilimsel bir teknik olarak güvenilirlik ve geçerlilik taşıması kadar nesnel, sayısal ve nicelikseldir (Atabek \& Atabek, 2007, p. 20). Nesnellik bulgularda araştırmacının etkisini sınırlandıırken, niceliksel olması sayısal verilerin sağladığı kesinlik algısı ile araştırmacının ifadesini güçlendirmesinde yatmaktadır (Krippendorff, 2004, pp. 18-20). 
Araştırmada sayısallaştııılan kavramlar öne çıkan konularla ilişkilendirilerek sosyal medya grup paylaşımlarındaki temel fenomenin belirlenebileceği düşüncesiyle içerik analiz tekniği tercih edilmiştir.

Çalışma amacına dayanarak alanyazın taranmış, belirlenen Facebook gruplarında yapılan paylaşımlar incelenmiş bu doğrultuda araştırmacılar tarafından kodlama cetveli oluşturulmuştur. Kodlama cetveli, mesaj tarihi, cinsiyet, paylaşımların niteliği, teması, bilgi verme, soru türü, şikâyetler, kullanılan ilaçlar, emojiler, beğeni sayısı, yorum sayısı, fotoğraflar/videolar, link, hashtag ve mention şeklinde 15 ana 59 yan kategoriden oluşmaktadır (Appendix 2). Tema kategorisinde rasyonel bilgi desteğini ölçmeye yönelik: Covid-19 şikâyetleri, uyarı/tavsiye, durum bildiriminde bulunma/deneyim, sağlıkla ilgili soru sorma, bilgi verme, bakıcılık hizmeti ilanı/reklam yer alırken; duygusal desteği ölçmeye yönelik:yakınma/isyan/sitem, iyi dilekler/teselli/dua/teşekkür yer almaktadır. Kodlama cetvelinin öntestle kodlayıcılar arası uyum yüzdesi ölçüm aracı genelinde \%92,95 olarak bulunmuştur (Table 1). Bu anlamda kodlama cetveli bu araştırma için yüksek güvenilirliktedir.

\section{Evren ve Örneklem}

Covid-19 pandemisinde izolasyon, karantina, mesafe tedbirleri bireyleri bilgi edinme sürecine dijital tabanlı uygulamaları kullanmaya zorlamaktadır. Covid-19 ile ilgili çok sayıda bilginin toplandığı ve depolandığı sosyal ağlar, hakkında çok fazla bilginin olmadığı Covid-19 pandemisinde risk taşıyan, kendisi ve yakınları hastalıktan etkilenenler için önemli bilgi kaynaklarıdır. Araştırmanın amacı Covid-19 pandemisinde sağlık arama davranışı gösteren kişilerin, Facebook gruplarında yaptıkları paylaşım ve yorumlara sağlık arayışının nasıl yansıdığını ortaya koymaktır. Bu kapsamda Facebook sosyal medya platformunda "Covid-19", “Covid-19 destek", “Korona”, “Korona virüs”, “Korona yardım”, "Covid-19 bilgi" kelime ve tamlamalarla arama yapılmış, üç grup belirlenmiştir. Türkçe paylaşımların yapıldığı 36 bin 98 katııımcıya sahip Corona virüsü (Covid-19) Bilgi Paylaşımı ve Yardımlaşma-Türkiye, 6 bin 564 katılımcıya sahip Covid-19 Bilgi Paylaşım Platformu ve 3 bin 423 katılımcıya sahip Covid-19 Yakalananlar Bilgi ve Birlik Platformu Türkiye Facebook gruplarında yapılan paylaşım ve yorumlar çalışmanın evrenini oluşturmuştur. Belirlenen Facebook gruplarında yapılan tüm paylaşım ve yorumların sayılarının fazla olması nedeniyle araştırmaya dâhil edilmesi mümkün değildir. Bu sebeple evrenden en güncel verilere ulaşmak amacıyla 07 Ekim ve 07 Ocak tarihleri arasında yapılan paylaşımlardan (ve yorum) basit rastlantısal örnekleme tekniği ile örneklem seçimi gerçekleştirilmiştir. 
Basit rastlantısal örnekleme tekniğinin tercih edilme sebebi evreni oluşturan her paylaşımın örnekleme girme şansının eşit olmasıdır. Bu yolla, hesaplamalarda da her paylaşıma verilecek ağırlık aynıdır. Yine evrendeki öğelerin her olası birleşiminin, örneklem içinde yer alması için eşit ihtimale sahip olmasına ek olarak, ele alınan problemlerle ilgili bilgilerin evrene göre benzeşik (homojen) olması da gerekmektedir (Kerlinger \& Lee, 1999). Yukarıda da ifade edildiği üzere araştırmada Covid-19 pandemisi ile ilgili katılımcıların (bilgi/destek gibi) paylaşım ve yorumlarının analiz edilmesi amaçlanmış olup, temel araştırma problemi evrene göre homojendir. Çalışmada 07 Ekim 2020 ve 07 Ocak 2021 tarihleri arasında 3747 paylaşımın olduğu (büyük grupta 1815, orta grup 1301 ve küçük grup 631) belirlenmiştir. Örneklem belirlenirken büyük gruptan 300, orta gruptan 200 ve küçük gruptan 100 paylaşım ve yorum araştırmaya dâhil edilmiştir (yaklaşık \%16). Farklı platformlardan farklı sayıda örneklem seçilmesinde sadece platformların katılımcı sayıları değil aynı zamanda verilerin anlamlı bir bütünlük sergilemesine imkân tanıması göz önünde bulundurulmuştur. Örneklemden elde edilen verilerin birbirini tekrar etmeye başlaması başka bir ifade ile veri doygunluğuna ulaşılması sebebiyle 600 sayısı örneklem için yeterli görülmüştür. Örneklemde yansızlığın sağlanması amacıyla Excell'in "S-Sayı Üret" işlevinden yararlanılarak, "0'dan büyük veya buna eşit ve 100 değerinden küçük rastgele bir sayı" seçilerek 7 Ocak 2021 tarihinden başlayarak geriye doğru her seferinde farklı bir sayı üretilerek ve o sayı kadar paylaşım atlanarak kodlama yapılmıştır. Paylaşımlarla birlikte paylaşımlara cevap niteliği taşıyan yorumlar ve paylaşım sahibinin cevabı araştırmanın örneklemine eklenmiştir. Böylece grup üyelerinin etkileşimi mesaj türü verilerine yansımıştır, bu da sosyal medya gruplarının özelliğini belirlemek açısından önemlidir.

\section{İşlem}

Öncelikle örneklem kapsamında belirlenen Facebook grup katılımcıları ve moderatörlere bilgilendirme yapılmış ve ön test için 01.12.202 ve 01.01.2021 tarihleri arasında "Covid-19 Bilgi Paylaşım Platformu" Facebook grubundan 60 paylaşım ve yorum (örneklem toplamının yüzde $10^{\prime} \mathrm{u}$ ) belirlenen kategorilere göre birbirinden bağımsız iki kodlayıcı tarafından SPSS 22.0 analiz programında kodlanmıştır. Bu sırada gerek duyulduğunda ek kategoriler eklenmiştir. Ön testle elde edilen verilerin güvenilirlik analizi yapılarak kodlayıcılar arasında uzlaşım sağlanmış, tüm kategoriler genelinde güvenilirliği düşük çıkanlar kodlama cetvelinden çıkarılmıştır (Miles \& Huberman, 1994). Çalışmanın devamında 07 Ekim 2020 ve 07 Ocak 2021 tarihleri arasında 600 ana mesaj ve yorum kodlanmıştır. Veriler SPSS 22.0 analiz programı kullanılarak frekans dağılımlarına 
göre sıralanmış ve mesaj tarihi, grup üyelerinin cinsiyeti, Facebook grubu değişkenine göre ki-kare testi ile iki veya daha fazla veri seti arasında farkın olup olmadığı incelenmiştir. Alanyazın incelemesinde özellikle cinsiyete dayalı olarak sağlık arama davranışının farklılaştığı belirlenmiştir, ayrıca sosyal ağlara göre tema ve kategorilerdeki farklılık ağların kuruluş ve kullanım amacındaki farklıı̆ı ortaya koymaktadır. Bu nedenle başta cinsiyete ve gruplara göre kategoriler arasındaki farklılık ki-kare testiyle ortaya konmuştur. Ana mesaj ve yorumlar daha sonra Excell'e kopyalanmış her ana mesaj ve yorum tabloda bir sırayı/birimi ifade edecek şekilde sıralanmıştır. Excell'e aktarılan kelimelerin sıklığına göre Python programlama dilinde kelime bulutu çıkarılmıştır (Figure 6). Programlama dili kullanılırken şu parametreler göz önünde bulundurulmuştur:

- 8'den daha az tekrar eden kelimeler karmaşadan kaçınmak amacıyla analize dâhil edilmemiştir. Böylece bulut "versin" ( $f=113)$ ve "dilerim" ( $f=9$ ) kelimeleri arasında sınırlandırılmıştır.

- Ana mesaj ve yorumlardaki tek başına bir anlam ifade etmeyen "ve", "ne", "kim" gibi bağlaç ve edatların tamamı analizden çıkarılmıştır.

- Kullanıııların isimleri, kodlamada elde edilen bağlamın dışında kalan, anlamsız rakam, sayı ve kelimeler analizden çıkarılmışır.

- Sadeleşen yapı programlama diline aktarılmıştır.

\section{BULGULAR}

Bu bölümde çalışmanın bulguları iki ayrı başlık altında değerlendirilmiştir. Illk olarak Covid-19 konulu paylaşım ve yorumların genel görünümü başlığı altında paylaşımların ayı, paylaşan kişinin cinsiyeti, paylaşımların niteliği ve kullanılan emoji, link ve hastag gibi ayrıntılara değinilmiştir. Covid-19 konulu paylaşım ve yorumların içerikleri başı̆̆ı altında ise paylaşımların temaları, verilen bilgilerin, sorulan soruların, şikâyetlerin ve kullanılan ya da önerilen ilaçların niteliğine ilişkin bulgular detaylandırılmıştır.

\section{Covid-19 Konulu Paylaşım ve Yorumların Genel Görünümü}

Araştırma kapsamında Facebook gruplarında Covid-19 içerikli paylaşım ve yorumların aylara göre dağılımı incelenmiştir. 600 paylaşım ve yorum ağırlıklı olarak Ocak 2021'e aittir, bu ayda \%57,2 ( $f=343$ ) paylaşım ve yorum yapılmıştır, \%27,3'ü ( $f=164)$ Aralık, $\% 14^{\prime u ̈ ~(~} \mathrm{f}=84$ ) Kasım ve \%1,5'i ( $\mathrm{f}=9$ ) Ekim ayında yapılmıştır. Paylaşım ve yorumların üyelerin cinsiyetine göre dağılımı incelendiğinde \%54'ünün (f=324) ağılıklı olarak 
kadınlar tarafından yapılması söz konusudur, erkekler \%42,3 ile ( $f=254)$ ikinci sıradadır. $\% 3,7$ oranında ( $\mathrm{f}=22$ ) hangi cinsiyetten yapıldığı tahmin edilememektedir, bu paylaşımlar kurumsal hesaplardan yapılmıştır.

Paylaşım ve yorumların nitelik dağılımı incelendiğinde $\% 13,7$ 'sinin ( $f=82$ ) ana paylaşım, $\% 70,5^{\prime}$ inin ( $f=423$ ) yorum ve \%15,8'inin ( $f=95$ ) ana paylaşımı yapan kişinin yorumculara geri dönüşü olduğu belirlenmiştir. Ki-kare testi sonucuna göre kadınlar en fazla ana mesaj ve yorum, erkekler ise en fazla yorumcuya cevap paylaşımı yapmıştır $\left(X^{2}=93,57\right.$, $\mathrm{df}=6, \mathrm{p}<, 000)$. En fazla ana mesaj Covid-19 Bilgi Paylaşım Platformu'nda (\%54,94), ikinci sırada Covid-19 Yakalananlar Bilgi ve Birlik Platformu Türkiye'de yapılmıştır $(\% 11,2)$. En çok yorum ise (\%40) Corona virüsü (Covid-19) Bilgi Paylaşımı ve Yardımlaşma-Türkiye grubunda yapılmıştır $\left(X^{2}=104,58, d f=6, p<, 005\right)$.

600 ana mesaj ve yorumda toplam 353 beğeni yer almaktadır.120 üzüntü, 54 dua, 4 parçalanmış kalp, 1 şaşkınlık, 1 kalp emojisi bulunmaktadır. İçeriklerde toplam 40 fotoğraf/video, 1 link, 1 hashtag söz konusudur. Fotoğraflar arasında tahlil, film, ilaç kutusu gibi paylaşımların olduğu tespit edilmiştir. Link paylaşımında ise bir habere işaret edilmektedir.

\section{Covid-19 Konulu Paylaşım ve Yorumların İçerikleri}

Araştırmada Covid-19 konulu sosyal medya paylaşımlarının temasına ilişkin bulgular yer almaktadır (Figure 1). Buna göre ağırlıklı olarak, \%35,3 oranında"iyi dilekler/teselli/ dua/teşekkür" içeren paylaşım ve yorumlar bulunmaktadır. \%25,3'ü "durum bildiriminde bulunma/deneyim paylaşma" ve \%15'i "sağlığa ilişkin soru sorma" temasından oluşmaktadır. \%7 oranında "uyarı/tavsiye", \%6,8 ile "bilgi verme", \%6 oranında "Covid-19 şikâyetleri", \%2,3 ile "yakınma/isyan/sitem" teması izleyen diğer içeriklerdir. İçeriklerde "bakıcılık hizmeti ilanı/reklam" olan 12 (\%2) paylaşım ve yorum vardır. Ki-kare testi sonucuna göre Corona virüsü (Covid-19) Bilgi Paylaşım ve Yardımlaşma-Türkiye grubunda en çok "iyi dilekler/teselli/dua/teşekkür" (\%32,5), "durum bildiriminde bulunma/deneyim" (\%11), Covid-19 Bilgi Paylaşım Platformu'nda "bilgi verme" (\%6,8), "sağlığa ilişkin soru sorma" $(\% 7,2)$, "uyarı/tavsiye" $(\% 4,8)$, "Covid-19 şikâyeti" $(\% 3,2)$ temasında paylaşım ve yorum yapılmıştır ( $\left.X^{2}=338,46, d f=16, p<, 001\right)$. Ayrıca aylara göre dağılım incelendiğinde en fazla Ocak ayında "iyi dilekler/teselli/dua/teşekkür" temasında paylaşım ve yorum yapılmıştır ( $\left.X^{2}=203,57, d f=24, p<, 005\right)$. Yine en fazla kadınlar "iyi dilekler/teselli/dua/ teşekkür", erkekler "durum bildirimi/deneyim", cinsiyet kategorisi belirli olmayan grup 
katılımcıları "bilgi verme" temasında paylaşım ve yorum yapmıştır $\left(X^{2}=170,42, \mathrm{df}=16\right.$, $\mathrm{p}<, 000)$.

Bilgi verme kategorisinde sırasıyla "belirtiler" $(\% 20,1)$, "ilaç kullanımı” $(\% 17,3)$, "bulaşım/ nasıl bulaştığı" (\%13,7), "tedavi” (\%10,1), "önlem" (\%7,9), "ölü/vaka sayısı" (\%5,8), "aşı" (\%5), "test" (\%5), "karantina" (\%4,3), "yan etkiler" (\%4,3), "virüs seyri/mutasyon" (\%4,3), "doktor/hastane" (\%2,2) olduğu belirlenmiştir (Figure 2). Ki-kare testi sonucuna göre bilgi vermede en yüksek düzeyde Covid-19 Bilgi Paylaşım Platformu'nda en fazla "bulaşım/nasıl bulaştığı", "ilaç kullanımı” ve "aşı”ya dair paylaşım ve yorum yapılırken, Corona virüsü (Covid-19) Bilgi Paylaşımı ve Yardımlaşma-Türkiye'de "test", "belirtiler", "önlem" ve "tedavi" alt kategorisinde, Covid-19 Yakalananlar Bilgi ve Birlik Platformu Türkiye'de ise "yan etkiler" kategorisinde paylaşım ve yorum yapılmıştır $\left(X^{2}=119,08 \mathrm{df}\right.$ $=24, p<, 000$ ). Kadınlar en çok "bulaşım/nasıl bulaştığı", "ilaç kullanımı”, erkekler ise "belirtiler", "tedavi" hakkında bilgi paylaşmıştır $\left(X^{2}=172,98, d f=24, p<, 000\right)$.

Araştırmada bilgi ihtiyacını karşılamak amacıyla kullanıcılar tarafından soru niteliği taşıyan paylaşım ve yorumların yer aldığı belirlenmiştir (Figure 3). Soru türünün \%41,3'ü "deneyim/tedavi" sorusudur. Onu "ilaç" (\%23,7), "ağrı/acı/yan etki" (\%15,5), "tahlil yorumu" (\%10,3), "doktor/hastane" (\%6,1), "Covid-19 genel durum" $(\% 3,1)$ soruları izlemektedir. Ki-kare testi sonucuna göre soru kategorisinde Corona virüsü (Covid-19) Bilgi Paylaşımı ve Yardımlaşma-Türkiye'de "deneyim/tedavi", Covid-19 Bilgi Paylaşım Platformu'nda "ağrı/acı/yan etki", "ilaç" soruları, "tahlilleri atıp yorum sorma" alt kategorisinde paylaşım ve yorum yapılmıştır $\left(X^{2}=59,37, d f=12, p<, 005\right)$. Erkekler en çok "deneyim/tedavi" sorusu sormaktadır, diğer alt kategorilerde kadınlar yer almaktadır $\left(X^{2}=21,40, d f=12, p<, 05\right)$.

Araştırmada paylaşım ve yorumlarda ne tür şikâyetlerin yer aldığı belirlenmiştir (Figure 4). En fazla paylaşılan şikâyet türü "vücuttaki ağrılar"dır ( $f=21 ; \% 15,9)$. Onu "tat/ koku kaybı" ( $f=15 ; \% 11,5)$, "öksürük" ( $f=12 ; \% 9,2)$, "nefes darlıkları" $(f=10 ; \% 7,6)$ ve "ateş" $(f=9 ; \% 6,8)$ izlemektedir. Diğer kategorisindeki şikâyetler ise şunlardır: "Bulantı" $(f=4)$, "geniz akıntısı" ( $f=4)$, "ishal" ( $f=4)$, "ağız kokusu" ( $f=4)$, "sinüzit" ( $f=3)$, "mide ağrısı" ( $f=3)$, "terleme" ( $f=3)$, "titreme" ( $f=2)$, "burunda tıkanıklık" $(f=2)$, "kalpte batmalar" $(f=2)$, "reflü" $(f=2)$, "sırtta yanma hissi" ( $f=1)$, "üşüme" $(f=1)$, kalıcı sağlık sorunları $(f=1)$, baş ağrısı" $(f=1)$. Kadınlar en fazla "tat ve koku kaybı" ile "vücutta batmalar"dan şikâyet ederken erkekler en çok"nefes darlığı/astım"dan şikâyet etmektedir. 
Paylaşım ve yorumlarda Covid-19 sürecinde kullanılan ya da önerilen ilaçlara yönelik bilgilerin yer aldığı belirlenmiştir (Figure 5). Buna göre ağırlıklı olarak "uzman doktorun önerdiği Covid-19'a özel ilaçlar" (\%37,1), "bitkisel öneriler" $(\% 29,1)$ yer almaktadır. Bu bulgu üyelerin bitkisel tedavilere olan duyarlıı̆ı̆ını yansıtması bakımından önemlidir. "Kan sulandırıcılar" ( $f=12)$, "antibiyotikler" $(\mathrm{f}=5)$, "probiyotikler" $(\mathrm{f}=3)$ ve "mide koruyucular" $(\mathrm{f}=1)$ kullanılan ya da önerilen diğer ilaçlardır.

\section{TARTIŞMA VE SONUÇ}

Facebook'ta kişi ve sivil toplum kuruluşları tarafından oluşturulan üç grupta paylaşım ve yorumlar sağlık arama davranışı bağlamında incelenmiş yorumların paylaşımlardan fazla olduğu belirlenmiştir, gruplarda güçlü bir etkileşim vardır. Paylaşım ve yorumların içeriği incelendiğinde daha önceki çalışmaların aksine (Zhang et al., 2013; Thoren et al., 2013; Hale et al., 2014; Bozkanat, 2018; Mitchell \& Grieve, 2020) doğrudan bilgi desteğinden çok duygusal destek paylaşım ve yorumlarının yer aldığı belirlenmiştir. Paylaşımlar ve yorumlar paylaşım yapan kişinin korku ve endişesini azaltmaya yönelik destek sağlama amacı taşımaktadır. Diğer bir ifadeyle hakkında çok şey bilinmeyen Covid-19 pandemisinden kaynaklanan ruhsal baskıyı azaltmaya yöneliktir. Kelime bulutundan da anlaşılacağı gibi duygusal destek dini terminoloji kullanılarak verilmektedir. Çoğunlukla dua ve acil şifa temennilerinden oluşmaktadır. Çalışma bu bakımdan diğer çalışmalardan farklılık göstermektedir.

Facebook sosyal medya gruplarında katılımcılar deneyimlerini paylaşmakta, kendi ya da yakınlarının hastalık seyri ile ilgili durum bildiriminde bulunmaktadır. Bu alt temada benzer çalışmalar yer almaktadır (Nahm et al., 2009; AlQarni et al., 2016; Bozkanat, 2018). Sosyal medya gruplarında "grup aidiyeti" nedeniyle sayfa üyelerinin birbirlerinden haberdar olma, birbirlerini haberdar etme isteği yüksektir (Mitchell \& Grieve, 2020). Aynı zamanda bulaştan etkilendiği andan tedavi sürecine kadar yaşananların tüm ayrıntısına kadar anlatılığı paylaşımlara rastlanmıştır. Benzer belirtiler gösteren kişilerin kendi hastalıklarına tanı koymada bu tür deneyim paylaşımları katkı sağlamaktadır. Bu tür paylaşımlar Covid-19 pandemisinde bilgi boşluğunun neden olduğu korku ve paniği azaltabilir niteliktedir.

Facebook gruplarında haber ve bilimsel bilgi niteliğinde paylaşımlarda bulunulmaktadır. Bu bilgiler haber sitelerinden link, fotoğraf, hashtag kullanılarak, ana 
mesaj olarak paylaşılabileceği gibi, gruptaki sağlık çalışanları tarafından ana mesaja yorum olarak da sunulmaktadır. Facebook gruplarında en fazla belirtilere yönelik bilgi paylaşılmakta böylece Covid-19 ile ilgili farkındalık oluşturulmaktır (Thoren et al., 2013; Öztürk \& Öymen, 2014; Mamun et al., 2015). Facebook gruplarının oluşum amaçlarından biri de yaygın görülen sağlık problemine ilişkin farkındalık yaratmaktır. Özellikle kanser gibi öldürücü, HIV/AIDS gibi bulaşıcı hastalıkları konu alan sosyal medya paylaşımlarında bu amaç daha belirgindir (DeSouza \& Jyoti Dutta, 2008; Taggart et al., 2015).

Paylaşım ve yorumlarda sağlıkla ilgili soru sorma doğrudan bir sağlık arama davranışıdır. Deneyim, sağlık hizmeti desteği, hastane, belirtiler, tedavi süreci, kullanılan ilaçlar, tahlillerin sonucu, yan etkiler (Shuyler \& Knight, 2003; Mamun et al., 2015; AlQarni et al., 2016; Cangelosi et al., 2018) gibi bir çok konuda sorulan soruların cevabı diğer üyelerin verdiği yorumlarda aranmaktadır. Yorum yapan katılımcıların deneyimlerinden kendi hastalığına yönelik çıkarımlar yapılmaktadır. Paylaşım ve yorumlarda katılımcılar tahlil-test sonuçlarını içeren görselleri paylaşmakta ve diğer katılımcıların bu görselleri yorumlamaları istenmektedir. Böylece gruptaki uzman ya da hastalığı deneyimleyenlerden kendi ya da yakınlarının durumu hakkındaki bilgi edinme çabası içine girilmektedir.

Cinsiyet farklılı̆ının Facebook gruplarında sağlık aramada belirleyici olduğu tespit edilmiştir. Kadınlar paylaşım ve yorum sayıları, paylaşımların niteliği bakımından erkeklerden farklılık göstermektedir. Facebook gruplarını farklı kullanım pratiğine sahiptirler. Gruptaki kadın katılımcılar etkileşime açıktır ve bilgi paylaşımında olduğu gibi, diğer katılımcılardan destek almada, duygularını ifade etmede daha istekli davranmaktadır. Zaman zaman kendilerinin zaman zaman aile yakınlarının şikâyetlerini ayrıntılandırarak paylaşmakta ve çekinmeden soru sormaktadır.

Çalışmada gruplar arası farklılık dikkat çekmektedir. Sosyal medya grubu katılımcılarının paylaşımlarındaki içerik farklıığı, grubun kurulum ve kullanım amacındaki farklıığı ortaya koymaktadır. Corona virüsü (Covid-19) Bilgi Paylaşım ve Yardımlaşma-Türkiye grubu etkileşime daha açık üyelerden oluşmaktadır. Grupta daha fazla duygusal destek amaçı ı paylaşım ve yorumlar yapılmaktadır. Deneyimlerini aktarmakta daha istekli katılımcılardan oluşmaktadır. Ancak Covid-19 Bilgi Paylaşım Platformu grubunda daha çok rasyonel bilgiler paylaşılmaktadır, etkileşim düzeyi en düşük gruptur. Bu grup paylaşımlarında aşı gibi güncel bilgilere daha fazla yer verilmektedir. 
Benzer konuda farklı çalışmalarda (Greene et al., 2011; Thoren et al., 2013; Zhang et al., 2013; Hale et al., 2014; AIQarni et al., 2016) bakıclık ve servis hizmeti, ürün tanıtımı paylaşımlarının sayısı azımsanmayacak kadar fazladır. Özellikle sağlık ürünü satan firmalar tarafından kurulan sosyal medya grupları ürün ve hizmet satışında tüketiciye erişim aracı olarak kullanılmaktadır. Bu çalışmada sınırlı sayıda olsa da yorumlara yapılan bitkisel ürün reklamlarına ve ana mesaj olarak yapılan bakıcı hizmeti ilanlarına rastlanmıştır.

Sosyal medyanın kendine has sorunsalı, gizlilik ve güvenilirlik (Fisher \& Clayton, 2012; Dau et al., 2020) Covid-19 konulu Facebook grubu paylaşımlarında da sorun oluşturmaktadır. Kullanıcıların heterojen yapısı, uzmanlık bilgilerinin olmaması ve aktardıkları bilgilere kendi yorumlarını katmaları problem olarak görülebilir. Mesleki yeterliliğe sahip olmayan katıımcıların başkalarına yardım etmek amacıyla yaptıkları paylaşımlar sağlık algısı ve sağlık okuryazarlık düzeyi düşük olan bireyler tarafından yanlış tedavinin uygulanmasına bununsa kalıcı ve kötü sonuçlar doğurmasında neden olabilmektedir. Ayrıca oluşan bilgi kirliliği nedeniyle gerçekte önemli bilgiler göz ardı edilmektedir. Bu nedenle gelecek araştırmacılara Facebook gruplarındaki katılımcıların medya-sağlık okuryazarlığı düzeyinin ölçülmesi önerilmektedir. Hali hazırda böyle bir araştırmaya rastlanmamıştır.

Sağlık arama davranışında internetin sık kullanımı siberkondri (internette hastalık arama hastalığı) olarak bilinen ruhsal probleme neden olmaktadır (Baumgartner \& Hartmann, 2011; Karaer-Karapıçak et al., 2012; Altındiş et al., 2018). Öyle ki bireyler kullanım kolaylığı nedeniyle internet ve sosyal ağlarda sağlıkla ilgili bilgi arayışına gitmektedir. Bu arayışla edindikleri bilgilerin neden olduğu kaygı sonucunda bireyler yeniden yeni bilgi arayışına girmektedir, bu davranış bir süre sonra sık ve tekrarlarla devam etmekte, korku paradoksuna dönüşmektedir.

Diğer taraftan bazen kısıtlılık ve karantina gibi yüz yüze iletişim ve doktor desteğinin sağlanamadığı durumlarda ya da evde devam edilen tedavilerde internetin olanaklarından faydalanmak sağlıklı yaşamı kolaylaştırabilir. Aynı zamanda duygusal destek bazı ciddi hastalıklarda hastalığın seyri için önemli role sahiptir. Hastalar duygusal desteği benzer sorunlar yaşayan kişilerden alabilir ve sosyal medyada başlayan ilişkiler gerçek hayata taşınabilir. Bu bağlamda gelecek araştırmacılara sağlık bilgisi aramada sosyal medya gruplarının işlevselliği araştırma konusu olarak önerilmektedir. Katılımcıların sosyal medya gruplarını kullanımı ve gruplara katılım amaçlarına erişip erişmediği belirlenebilir. 
Ayrıca gelecek araştırmacılara hasta ve hasta yakınlarının içinde bulunduğu olumsuz psikolojik durumla başa çıkmada sosyal medya gruplarının etkisinin ölçülmesi önerilmektedir.

Bugün sosyal ağlar, Covid-19'un bulaşımı, tanısı, teşhis ve tedavisini içeren bilgilerin toplandığı ve depolandığı büyük veri özelliği taşımaktadır. Facebook, sosyal ağ üzerinde işlerlik kazanan bir sosyal medya platformudur. Bu nedenle Covid-19 gibi dünyayı saran sağlık krizlerinde ülkelerin sağlık politikalarının belirlenmesi, iyileştirmeler ve proaktif kriz yönetiminde Facebook gruplarından elde edilen veriler kaynak niteliğindedir.

\footnotetext{
Hakem Değerlendirmesi: Dış bağımsız.

Çıkar Çatışması: Yazarlar çıkar çatışması bildirmemiştir.

Finansal Destek: Yazarlar bu çalışma için finansal destek almadığını beyan etmiştir.

Yazar Katkısı: Çalışma Konsepti/Tasarımı: Ş.E.; Veri Toplama: Ş.E., A.F.; Veri Analizi /Yorumlama: A.F.; Yazı Taslağı: Ş.E., A.F.; Iç̧eriğin Eleştirel İncelemesi: Ş.E., A.F.; Son Onay ve Sorumluluk: Ş.E., A.F.

Peer-review: Externally peer-reviewed.

Conflict of Interest: The authors have no conflict of interest to declare.

Grant Support: The authors declared that this study has received no financial support.

Author Contributions: Conception/Design of study: Ş.E.; Data Acquisition: Ş.E., A.F.; Data Analysis/Interpretation: A.F.; Drafting Manuscript: Ş.E., A.F.; Critical Revision of Manuscript: Ş.E., A.F.; Final Approval and Accountability: Ş.E., A.F.
}

\section{ENDNOTES}

1 Kelime bulutu Python programlama dili kullanılarak hazırlanmıştır.

\section{REFERENCES}

Ağaçdiken-Alkan, S., Özdelikara, A., \& Boğa, N. M. (2017). Hemşirelik öğrencilerinin sağlık algılarıın belirlenmesi. Gümüşhane Üniversitesi Sağlık Bilimleri Dergisi, 6(2), 11-21.

Ahani, A., \& Nilahsi, M. (2020). Coronavirus outbreak and its impacts on global economy: The role of social network sites. Journal of Soft Computing and Decision Support Systems, 7(2), 19-22.

Ahorsu, D. K., Lin, C.-Y., Imani, V., Saffari, M., Griffiths, M. D., \& Pakpour, A. H. (2020). The fear of Covid-19 scale: Development and initial validation. International Journal of Mental Health and Addiction, 27, 1-9. https://doi. org/10.1007/s11469-020-00270-8

AIQarni, Z. A., Yunus, F., \& Househ, M. S. (2016). Health information sharing on Facebook: An exploratory study on diabetes mellitus. Journal of Infection and Public Health, 9(6), 708-712. https://doi.org/10.1016/j.jiph.2016.08.015

Alsisi, E. A., Al-Ashaab, A., \& Abualfaraa, W. A. (2020). The development of a smart health awareness message framework based on the use of social media: Quantitative study. Journal of Medical Internet Research, 22(7), e16212. https://doi.org/10.2196/16212 
Altındiş, S., İnci, M. B., Aslan, F. G., \& Altındiş, M. (2018). Üniversite çalışanlarında siberkondria düzeyleri ve ilişkili faktörlerin incelenmesi. Sakarya Medical Journal, 8(2), 359-370. https://doi.org/10.31832/smj.423652

Atabek, G. Ş., \& Atabek, Ü. (2007). Medya metinlerini çözümlemek: İçerik, göstergebilim ve söylem çözümleme yöntemleri ( $1^{\text {st }}$ ed). Ankara, Turkey: Siyasal Kitabevi.

Balhara, Y. S., Kattula, D., Singh, S., Chukkali, S., \& Bhargava, R. (2020). Impact of lockdown following Covid-19 on the gaming behavior of college students. Indian Journal of Public Health, 64(6), 172-176. https://doi. org/10.4103/ijph.IJPH_465_20

Bauman, Z. (2016). Cemaatler: Güvenli olmayan bir dünyada güvenlik anlayışı (N. Soysal, Trans.). İstanbul, Turkey: Say Yayınevi.

Baumgartner, S. E., \& Hartmann, T. (2011). The role of health anxiety in online health information search. Cyberpsychology, Behavior, and Social Networking, 14(10), 613-618. https://doi.org/10.1089/cyber.2010.0425

Bozkanat, E. (2018). Kitle-kişisel iletişim ile sağlık bilgisi arama: Bir Facebook grubu örneği. Iletişim Kuram ve Araştırma Dergisi, 46, 291-305.

Brashers, D. E., Goldsmith, D. J., \& Hsieh, E. (2002). Information seeking and avoiding in health contexts. Human Communication Research, 28(2), 258-271. https://doi.org/10.1111/j.1468-2958.2002.tb00807.x

Cangelosi, J., Kim, D., Ranelli, E., \& Griffin, K. (2018). A needs assessment study of what health care consumers seek from social media and social networking. Health Marketing Quarterly, 35(4), 266-279. https://doi.org/10 $.1080 / 07359683.2018 .1524595$

Covid-19 Hasta Tablosu (2021, January 13). Türkiye Cumhuriyeti Sağlık Bakanlığı. Retrieved from https://covid19. saglik.gov.tr/?gclid=CjwKCAiA6aSABhApEiwA6Cbm_3iQo2zZTjwxccXileXJyakKKPzM6vfVxPzUOzRxNBFkDFgeTbJMhoC3-sQAvD_BwE

Das, M., Angeli, F., Krumeich, A. J. S. M., \& van Schayck, O. C. P. (2018). The gendered experience with respect to health-seeking behaviour in an urban slum of Kolkata, India. International Journal for Equity in Health, 17(1), 24. https://doi.org/10.1186/s12939-018-0738-8

Dau, H., Saad El Din, K., McTaggart-Cowan, H., Loree, J. M., Gill, S., \& De Vera, M. A. (2020). Health information seeking behaviors among individuals with young-onset and average-onset colorectal cancer: An international cross-sectional survey. Supportive Care in Cancer, 28(12), 6011-6021. https://doi.org/10.1007/ s00520-020-05446-5

de la Torre-Díez, I., Díaz-Pernas, F. J., \& Antón-Rodríguez, M. (2012). A content analysis of chronic diseases social groups on Facebook and Twitter. Telemedicine Journal and E-Health: The Official Journal of the American Telemedicine Association, 6, 404-408. https://doi.org/10.1089/tmj.2011.0227

de la Vega, R., Almendros, L. J., Barquín, R. R., Boros, S., Demetrovics, Z., \& Szabo, A. (2020). Exercise addiction during the Covid-19 pandemic: An international study confirming the need for considering passion and perfectionism. International Journal of Mental Health and Addiction. https://doi.org/10.1007/s11469-020-00433-7 
Deloitte (2020, April 10). Küresel Covid-19 salgınının Türkiye'de farklı kategorilere etkileri. Retrieved from https:// www2.deloitte.com/tr/tr/pages/consulting/articles/kuresel-covid-19-salgininin-turkiyede-farklikategorilere-etkileri.html

Demirbilek, Y., Pehlivantürk, G., Özgüler, Z. Ö., \& Alp-Meşe, E. (2020). Covid-19 outbreak control, example of ministry of health of Turkey. Turkish Journal of Medical Sciences, 50, 489-494. https://doi.org/10.3906/sag2004-187

DeSouza, R., \& Jyoti Dutta, M. (2008). Global and local networking for HIV/AIDS prevention: The case of the Saathii e-forum. Journal of Health Communication, 13(4), 326-344. https://doi.org/10.1080/10810730802063363

Dsouza, D. D., Quadros, S., Hyderabadwala, Z. J., \& Mamun, M. A. (2020). Aggregated Covid-19 suicide incidences in India: Fear of Covid-19 infection is the prominent causative factor. Psychiatry Research, 290, 113145. https://doi.org/10.1016/j.psychres.2020.113145

Dube, L., Bourhis, A., \& Jacob, R. (2006). Towards a typology of virtual communities of practice. Interdisciplinary Journal of Information, Knowledge, and Management, 1, 069-093. https://doi.org/10.28945/115

Duman, N. (2020). Üniversite öğrencilerinde Covid-19 korkusu ve belirsizliğe tahammülsüzlük. The Journal of Social Science, 4(8). https://doi.org/10.30520/tjsosci.748404

Everett, J. A. C., Colombatto, C., Chituc, V., Brady, W. J., \& Crockett, M. (2020, Mart 20). The effectiveness of moral messages on public health behavioral intentions during the Covid-19 Pandemic. PsyArXiv Preprints, 2-23. https://doi.org/10.31234/osf.io/9yqs8

Fernandes, B., Biswas, U. N., Tan-Mansukhani, R., Vallejo, A., \& Essau, C. A. (2020). The impact of Covid-19 lockdown on internet use and escapism in adolescents. Revista de Psicología Clínica con Niños y Adolescentes, 7(3), 59-65. https://doi.org/10.21134/rpcna.2020.mon.2056

Fisher, J., \& Clayton, M. (2012). Who gives a tweet: Assessing patients' interest in the use of social media for health care. Worldviews on Evidence-Based Nursing, 9(2), 100-108. https://doi.org/10.1111/j.1741-6787.2012.00243.x

Fox, S., \& Duggan, M. (2013). Health online 2013. Pew Research Center Internet \& Technology. Retrieved from: https://www.pewresearch.org/internet/2013/01/15/health-online-2013/

Gallagher, S., \& Doherty, D. (2009). Searching for health information online: Characteristics of online health seekers. Journal of Evidence-Based Medicine, 2(2), 99-106. https://doi.org/10.1111/j.1756-5391.2009.01021.x

Gökler, M. E., \&Turan, Ş. (2020). Covid-19 pandemisi sürecinde teknoloji kullanımı önerileri. Eskişehir Türk Dünyası Uygulama ve Araştırma Merkezi Halk Sağlığı Dergisi, 5(Covid-19 Special Edition), 108-114. https://doi. org/10.35232/estudamhsd.767526

Greene, J. A., Choudhry, N. K., Kilabuk, E., \& Shrank, W. H. (2011). Online social networking by patients with diabetes: a qualitative evaluation of communication with Facebook. Journal of General Internal Medicine, 26(3), 287-292. https://doi.org/10.1007/s11606-010-1526-3

Griffiths, M. D., \& Mamun, M. A. (2020). Covid-19 suicidal behavior among couples and suicide pacts: Case study evidence from press reports. Psychiatry Research, 289, 113105. https://doi.org/10.1016/j.psychres.2020.113105 
Hale, T. M., Pathipati, A. S., Zan, S., \& Jethwani, K. (2014). Representation of health conditions on Facebook: Content analysis and evaluation of user engagement. Journal of Medical Internet Research, 16(8), e182. https://doi.org/10.2196/jmir.3275

Harper, C. A., Satchell, L. P., Fido, D., \& Latzman, R. D. (2020). Functional fear predicts public health compliance in the Covid-19 pandemic. International Journal of Mental Health and Addiction. https://doi.org/10.1007/ s11469-020-00281-5

Jacobs, W., Amuta, A. O., Jeon, K. C., \& Alvares, C. (2017). Health information seeking in the digital age: An analysis of health information seeking behavior among us adults. Cogent Social Sciences, 3(1), 1302785. https://doi. org/10.1080/23311886.2017.1302785

Karaer-Karapıçak, Ö., Aslan, S., \& Utku, Ç. (2012). Health anxiety in panic disorder, somatization disorder and hypochondriasis. Bilişsel Davranışçı Psikoterapi ve Araştırmalar Dergisi, 1(1), 43-51. Retrieved from https:// www.jcbpr.org/fulltext/77-1334223678.pdf.

Kerlinger, F. N., \& Lee, H. B. (1999). Foundations of behavioral research. New York, ABD: Harcourt College Publishers.

Kıraç, R. (2019). Sağlık arama davranışını etkileyen faktörler: Yapısal eşitlik modellemesine dayalı bir çalışma (Doctoral dissertation). Available from: https://toad.halileksi.net/sites/default/files/pdf/saglik-aramadavranisi-olcegi-toad.pdf

Kim, Y.M. (2015). Is seeking health information online different from seeking general information online? Journal of Information Science, 41(2), 228-241. https://doi.org/10.1177/0165551514561669

Kim, S. C., Shah, D. V., Namkoong, K., McTavish, F. M., \& Gustafson, D. H. (2013). Predictors of online health information seeking among women with breast cancer: The role of social support perception and emotional well-being: social support, emotional well-being, and online information seeking. Journal of ComputerMediated Communication, 18(2), 98-118. https://doi.org/10.1111/jcc4.12002

King, D. L., Delfabbro, P. H., Billieux, J., \& Potenza, M. N. (2020). Problematic online gaming and the Covid-19 pandemic. Journal of Behavioral Addictions, 9(2), 184-186. https://doi.org/10.1556/2006.2020.00016

Kircaburun, K., Yurdagül, C., Kuss, D., Emirtekin, E., \& Griffiths, M. D. (2020). Problematic mukbang watching and its relationship to disordered eating and internet addiction: A pilot study among emerging adult mukbang watchers. International Journal of Mental Health and Addiction. https://doi.org/10.1007/s11469-020-00309-w

Krippendorff, K. (2004). Content analysis: An introduction to its methodology (4 ${ }^{\text {th }}$ ed.). California, USA: SAGE Publications. Lambert, S. D., \& Loiselle, C. G. (2007). Health information—seeking behavior. Qualitative Health Research, 17(8), 1006-1019. https://doi.org/10.1177/1049732307305199

Li, Y., Wang, X., Lin, X., \& Hajli, M. (2018). Seeking and sharing health information on social media: A net an alence model and cross-cultural comparison. Technological Forecasting and Social Change, 126, 28-40. https://doi. org/10.1016/j.techfore.2016.07.021

Mamun, M. A., M. İbrahim, H., \& Turin, T. C. (2015). Social media in communicating health information: An analysis of Facebook groups related to hypertension. Preventing Chronic Disease, 12. https://www.cdc.gov/ pcd/issues/2015/14_0265a.htm 
Miles, M. B., \& Huberman, A. M. (1994). Qualitative data analysis: A methods sourcebook (2 ${ }^{\text {nd }}$ ed.). Arizona State University, USA: SAGE Publications.

Mitchell, G., \& Grieve, R. (2020). Using Facebook to gain health information and support: How attitude, norms, and locus of control predict women's intentions. Australian Psychologist, 55(6), 670-685. https://doi. org/10.1111/ap.12467

Nahm, E. S., Resnick, B., DeGrezia, M., \& Brotemarkle, R. (2009). Use of discussion boards in a theory-based health Web site for older adults. Nursing Research, 58(6), 419-426.

Öngel, Ö., Tarlı, H. S., \& Bozkurt, G. (2020). Küresel krizlerde kişilik özelliklerine göre sosyal medya algısı: Covid-19 örneği. Journal of Turkish Studies, 15(4), 827-851. https://doi.org/10.7827/TurkishStudies.43668

Öztürk, G., \& Öymen, G. (2014). Sağlık iletişiminde sosyal medya kullanımının stratejik önemi: Türkiye'de kalp sağlığı ile ilgili kâr amacı gütmeyen kuruluşlar üzerine bir değerlendirme. Galatasaray Üniversitesi Illetişim Dergisi, 109-132. Retrieved from http://iletisimdergisi.gsu.edu.tr/en/pub/issue/7383/96661

Qiu, J., Shen, B., Zhao, M., Wang, Z., Xie, B., \& Xu, Y. (2020). A nationwide survey of psychological distress among Chinese people in the Covid-19 epidemic: Implications and policy recommendations. General Psychiatry, 33(2), e100213. https://doi.org/10.1136/gpsych-2020-100213

Saricali, M., Satici, S. A., Satici, B., Gocet-Tekin, E., \& Griffiths, M. D. (2020). Fear of Covid-19, mindfulness, humor, and hopelessness: A multiple mediation analysis. International Journal of Mental Health and Addiction, 19, 1-4. https://doi.org/10.1007/s11469-020-00419-5

Satici, B., Saricali, M., Satici, S. A., \& Griffiths, M. D. (2020). Intolerance of uncertainty and mental wellbeing: Serial mediation by rumination and fear of Covid-19. International Journal of Mental Health and Addiction, 15, 1-12. https://doi.org/10.1007/s11469-020-00305-0

Schwartz, K. L., Roe, T., Northrup, J., Meza, J., Seifeldin, R., \& Neale, A. V. (2006). Family medicine patients' use of the internet for health information: A MetroNet study. The Journal of the American Board of Family Medicine, 19(1), 39-45. https://doi.org/10.3122/jabfm.19.1.39

Shuyler, K. S., \& Knight, K. M. (2003). What are patients seeking when they turn to the internet? Qualitative content analysis of questions asked by visitors to an orthopaedics Web site. Journal of Medical Internet Research, 5(4), e24. https://doi.org/10.2196/jmir.5.4.e24

Soraci, P., Ferrari, A., Bonanno, E., Rosanna, D. P., Repice, E., \& Griffiths, M. D. (2020). Psychometric validation of the internet disorder scale-short form in an Italian adult sample. International Journal of Mental Health and Addiction. https://doi.org/10.1007/s11469-020-00279-z

Taggart, T., Grewe, M. E., Conserve, D. F., Gliwa, C., \& Roman Isler, M. (2015). Social media and HIV: A systematic review of uses of social media in HIV communication. Journal of Medical Internet Research, 17(11), e248. https://doi.org/10.2196/jmir.4387

The Brand Age (2020). Koronavirüs Sosyal Medyaya Nasıl Yansıdı? Retrieved from https://www.thebrandage. com/koronavirus-sosyal-medyaya-nasil-yansidi-10410 
Thoren, E. M., Metze, B., Bührer, C., \& Garten, L. (2013). Online support for parents of preterm infants: A qualitative and content analysis of Facebook 'preemie' groups. Archives of Disease in Childhood - Fetal and Neonatal Edition, 98(6), F534-F538. https://doi.org/10.1136/archdischild-2012-303572

Türkiye Cumhuriyeti Sağlık Bakanlığı (2020, December 7). Covid-19 (Sars-Cov-2 enfeksiyonu) genel bilgiler, epidemiyoloji ve tanı. Retrieved from https://covid19.saglik.gov.tr/Eklenti/39551/0/covid-19rehberigenelbil gilerepidemiyolojivetanipdf.pdf

Wang, C., Pan, R., Wan, X., Tan, Y., Xu, L., Ho, C. S., \& Ho, R. C. (2020). Immediate psychological responses and associated factors during the initial stage of the 2019 Coronavirus disease (Covid-19) epidemic among the general population in China. International Journal of Environmental Research and Public Health, 17(5), 1729. https://doi.org/10.3390/ijerph17051729

We Are Social (2020). Digital 2020. Retrieved from https://wearesocial.com/blog/2020/07/digital-use-aroundthe-world-in-july-2020

Wellman, B. (2001). Physical place and cyberplace: The rise of personalized networking. International Journal of Urban and Regional Research, 25(2), 227-252. https://doi.org/10.1111/1468-2427.00309

Word Health Organization (2021, January 13). WHO coronavirus disease (Covid-19) dashboard. Retrieved from https://covid19.who.int/region/euro/country/tr

You (Ryu), K. H., \& Cho, J. (2020). Investigation of the influential factors in leading people to seek mobile information for the promotion of health-related behaviors. Sustainability, 12(24), 10512. https://doi. org/10.3390/su122410512

Yum, S. (2020). Social network analysis for Coronavirus (Covid-19) in the United States. Social Science Quarterly, 101(4), 1642-1647. https://doi.org/10.1111/ssqu.12808

Zhang, Y., He, D., \& Sang, Y. (2013). Facebook as a platform for health information and communication: A case study of a diabetes group. Journal of Medical Systems, 37(3), 9942. https://doi.org/10.1007/s10916-013-9942-7

Zitek, E. M., \& Schlund, R. J. (2020). Psychological entitlement predicts noncompliance with the health guidelines of the Covid-19 pandemic. Personality and Individual Differences, 110491. https://doi.org/10.1016/j. paid.2020.110491 


\section{TABLES AND FIGURES}

Table 1: Kodlayıcılar Arası Güvenilirlik Oranının Başlıca Kategorilere Dağılımı

\begin{tabular}{|l|c|c|c|c|c|c|c|}
\hline Kategori & Nitelik & Tema & Soru türü & Bilgi türü & $\begin{array}{c}\text { Şikâyet } \\
\text { türü }\end{array}$ & $\begin{array}{c}\text { Kullanılan } \\
\text { ilaçlar }\end{array}$ & GENEL \\
\hline $\begin{array}{l}\text { Toplam kod- } \\
\text { lama }\end{array}$ & 120 & 120 & 26 & 58 & 76 & 26 & 426 \\
\hline Ortak kodlar & 60 & 53 & 13 & 25 & 36 & 11 & 198 \\
\hline $\begin{array}{l}\text { Güvenilirlik } \\
\text { oranı }\end{array}$ & $\% 100$ & $\% 88,33$ & $\% 100$ & $\% 86,20$ & $\% 94,73$ & $\% 84,61$ & $\% 92,95$ \\
\hline
\end{tabular}

Figure 1: Facebook Grup Katılımcıları Tarafından Paylaşılan Covid-19 Konulu İçeriklerin Tema Kategorisine Göre Dağılımı

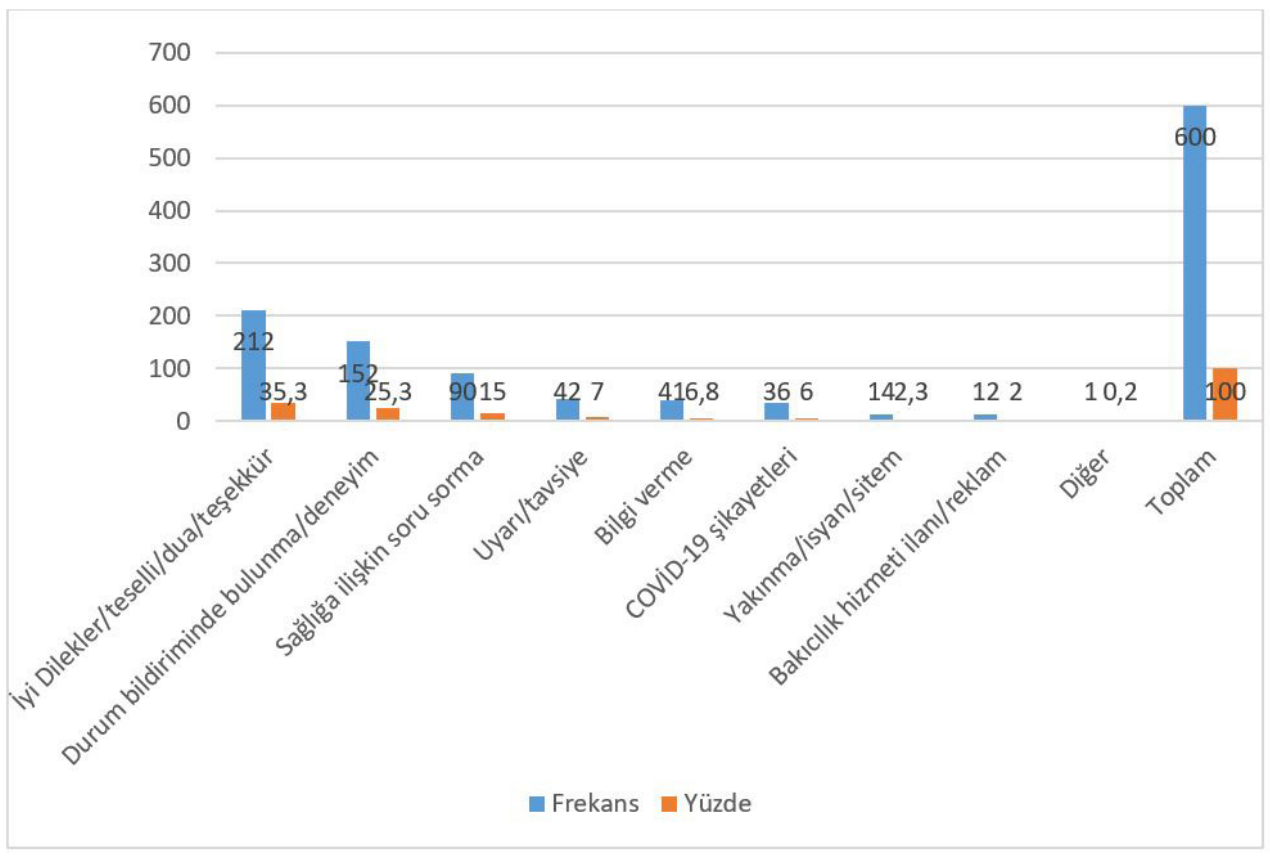


Figure 2: Facebook Grup Paylaşımlarının İçeriğinin Bilgi Alt Temasına Göre Dağılımı

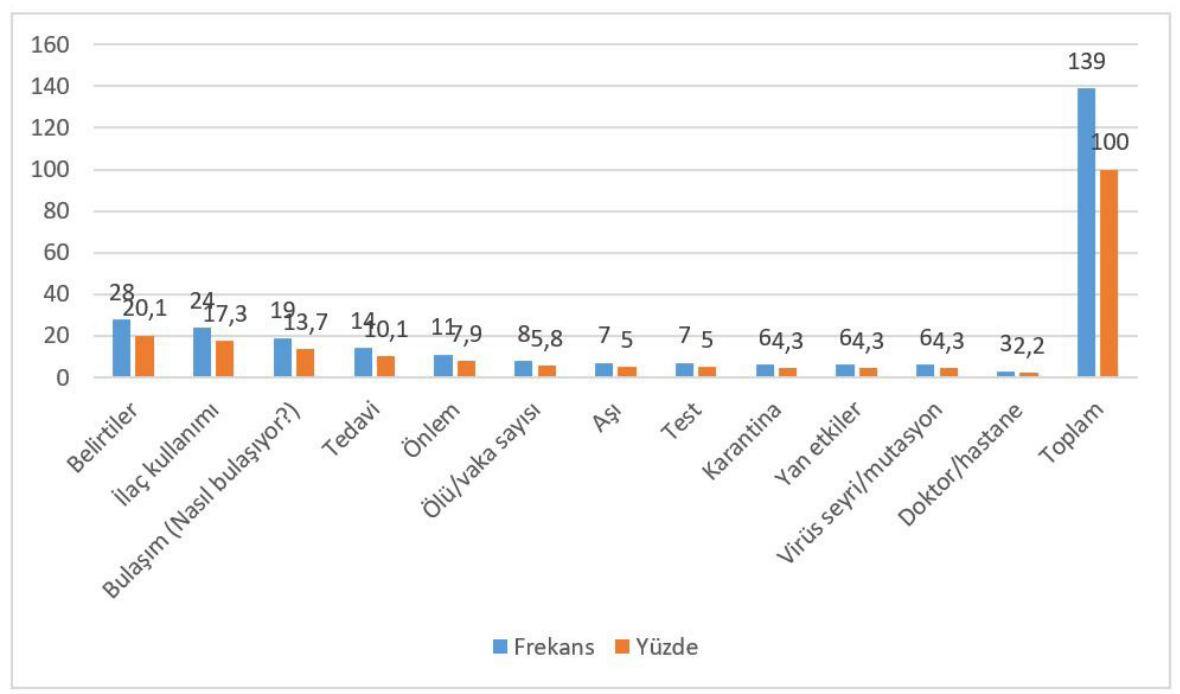

Figure 3: Grup Paylaşımlarında Hasta ve Hasta Yakınları Tarafından Covid-19'a İlişkin Sorulan Soruların Türlerine Göre Dağılımı

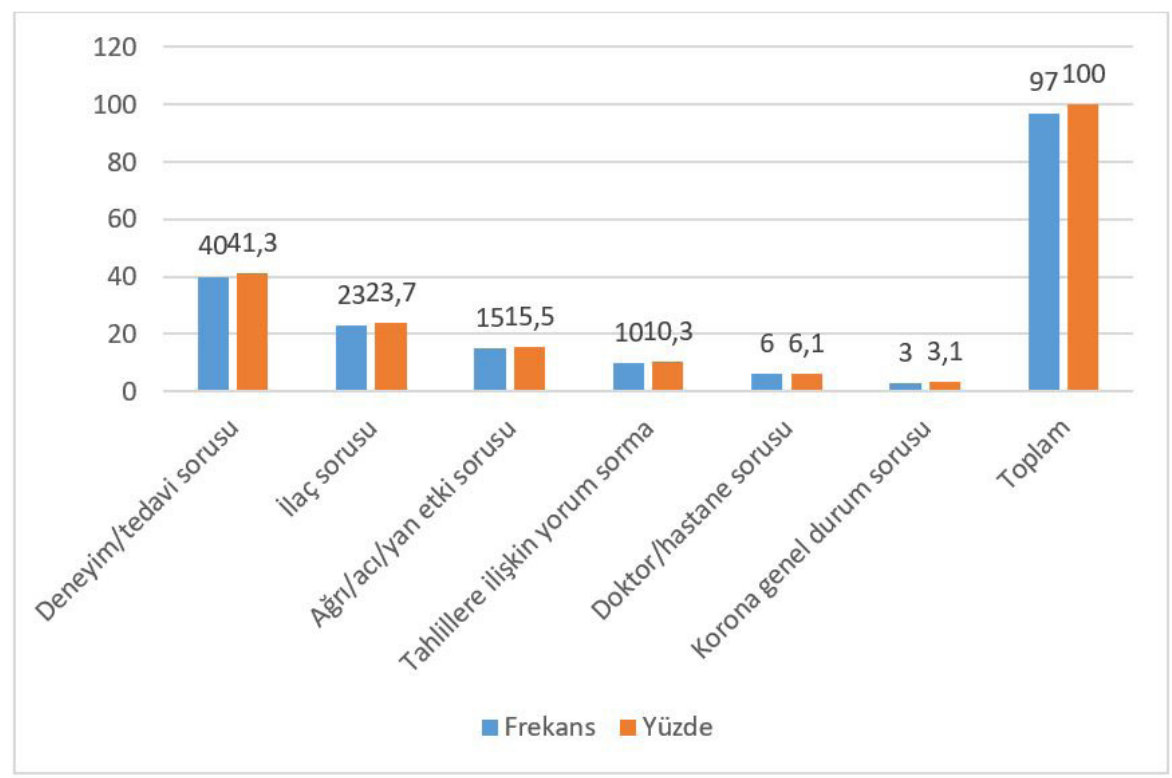


Figure 4: Facebook Grup Paylaşımlarındaki Covid-19 Nedeniyle Oluşan Şikâyetlerin Türüne Göre Dağılımı

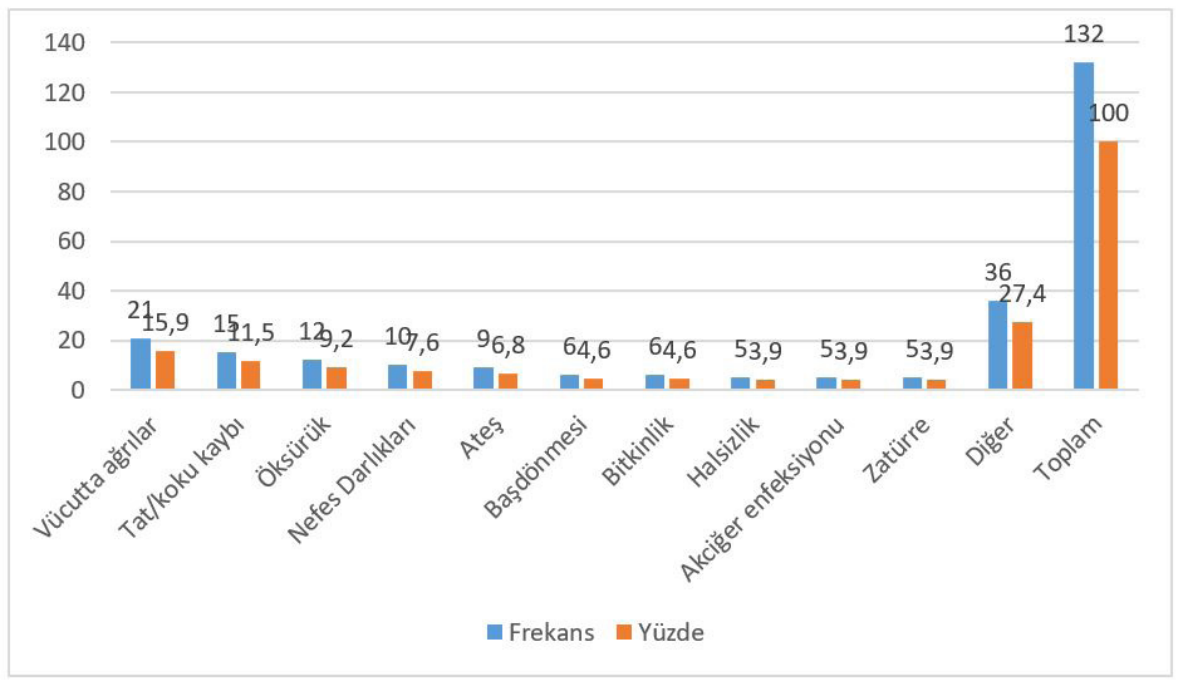

Figure 5: Grup Paylaşımlarında Katılımcılar Tarafından Covid-19 Sürecinde Kullanıldığı Belirtilen ya da Diğer Katıımcılara Önerilen Illaç Türlerinin Dağııımı

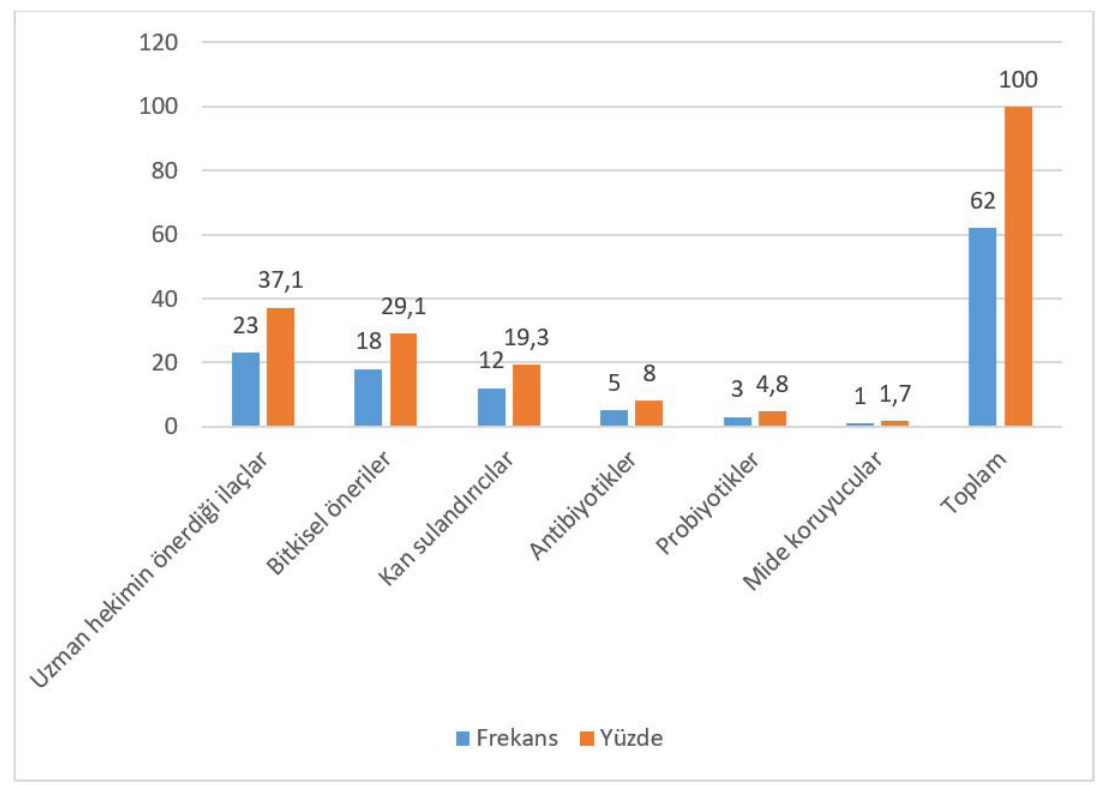

Note: Figure 5'te "uzman hekimin önerdiği ilaçlar", paylaşımların içeriğinden Covid-19 tedavi sürecinde kullanıldığı anlaşılan hekim tarafından düzenlenen reçete ile temin edilen ilaçları kapsamaktadır. "Bitkisel öneriler" yine bu süreçte bitkisel tedaviye yönelik kullanıldığı belirtilen ya da diğer katılımcılara önerilen ek ürünleri ifade etmektedir. "Kan sulandırıcılar" "antibiyotikler", "probiyotikler" ve "mide koruyucular" da bu kelimelerle ifade edilen, hastalık sürecinde kullanıldığı belirtilen ya da önerilen markanın yer almadığı ilaçları belirlemek için kullanılan alt kategorilerdir. 
Figure 6: Facebook Gruplarında Yapılan Covid-19 Konulu Paylaşımlarda En Fazla Tekrar Edilen Kelimeler Bulutu

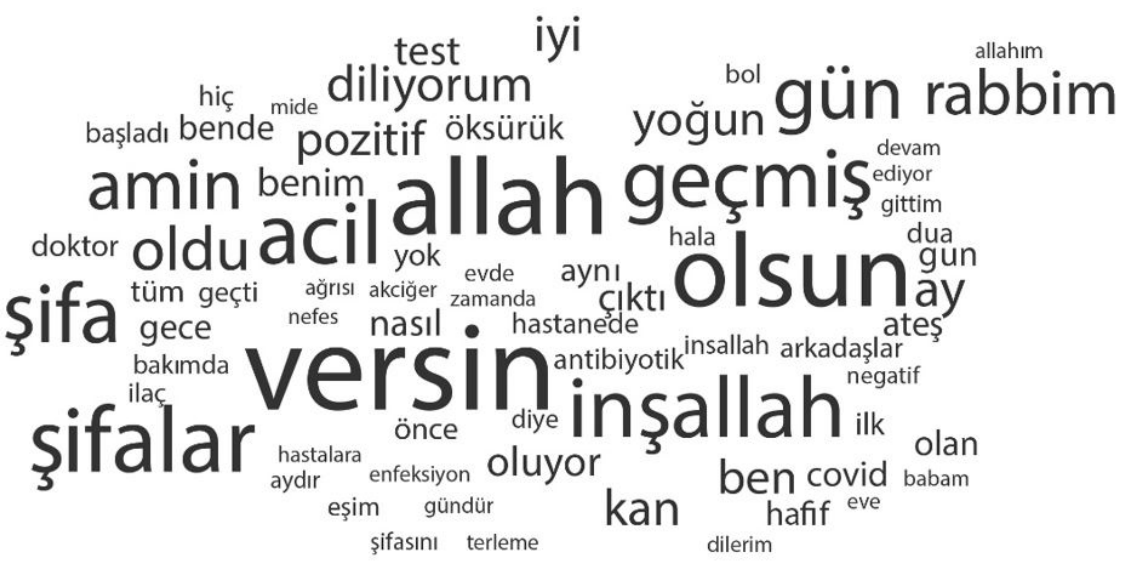




\section{APPENDICES}

Appendix 1: Kodlayıcılar Arası Uyum

"Covid-19 Bilgi Paylaşım Platformu" grubunda ana mesaj ve yorum toplamda 60 paylaşım (örneklem toplamının yüzde 10'u) iki kodlayıcı tarafından kodlanmış, verilerin güvenilirlik analizi yapılarak güvenilirliği düşük çıkan tema ve kategoriler kodlama cetvelinden çıkarılmıştır

Kodlayıcılar Arası Uyum Formülü

1. Kodlayıcı toplam kodlama+2. Kodlayıcı toplam kodlama

2x (Üzerinde uzlaşılan kod sayısı)

Miles ve Huberman (1994)

\section{Appendix 2: Kodlama Cetveli}

\section{Tarih}

\section{Cinsiyet}

Kadın

Erkek

Bilinmiyor

\section{Nitelik}

Ana mesaj

Cevap

Ana Mesajı Yazan Kişinin Yorumcuya Cevabı

\section{Tema}

Covid-19 Şikâyetleri

İyi Dilekler/teselli/dua/teşekkür

Yakınma/isyan/sitem

Uyarı/tavsiye

Durum Bildiriminde Bulunma/deneyim

\section{Bilgi Verme}

(alt kategoriler)

1. Belirtiler

2. İlaç Kullanımı

3. Bulaşım/nasıl bulaştığı 
4. Tedavi

5. Önlem

6. Ölü/vaka Sayısı

7. Aşı

8. Test

9. Karantina

10. Yan Etkiler

11. Virüs seyri/mutasyon

12. Doktor/hastane

\section{Sağlığa İlişkin Soru Sorma}

(alt kategoriler)

1. Deneyim/tedavi sorusu

2. İlaç Sorusu

3. Ağrı/acı/yan Etki Sorusu

4. Tahlillere İlişkin Yorum Sorusu

5. Doktor/hastane sorusu

6. Korona Genel Durum Sorusu

Bakıcılık Hizmeti İlanı/reklam

Diğer

\section{Şikâyet Türü}

Vücutta Ağrılar

Tat/Koku Kaybı

Öksürük

Nefes Darlıkları

Ateş

Baş Dönmesi

Bitkinlik

Halsizlik

Akciğer Enfeksiyonu

Zatürre

Diğer

\section{Kullanılan/Önerilen İlaçlar}

Uzman Hekimin Önerdiği İlaçlar

Bitkisel Öneriler

Kan Sulandırıcılar 


\section{Antibiyotikler}

\section{Probiyotikler}

Mide Koruyucular

\section{Emoji Sayıları ve Türü}

1. Üzüntü

2. Dua

3. Kalp

4. Parçalanmış Kalp

5. Şaşkınlık

\section{Beğeni sayısı}

\section{Yorum sayısı}

\section{Fotoğraflar/videolar}

\section{Link}

\section{Hashtag}

\section{Mention}

Appendix 3: Tema Kategorisinin Alt Kategorileri ve Örnek Ifadeler

\begin{tabular}{|l|l|}
\hline Tema alt kategorisi & Örnek ifadeler \\
\hline Covid-19 şikâyetleri & $\begin{array}{l}\text { Boğaz yanması tat ve kuku alma kaybı ile birlikte hal- } \\
\text { sizlik ve şiddetli kas ve eklem ağrısı ... gibi belirtilerle } \\
\text { başladı. (Yorum) }\end{array}$ \\
\hline İyi dilekler/teselli/dua & $\begin{array}{l}\text { Allah'ım sana yalvarıyorum kullarına yardım et diye } \\
\text { dua ediyorum Allahım virüssüz bir dünya dilerim ..." } \\
\text { (Ana mesaj). }\end{array}$ \\
\hline Yakınma/isyan/sitem & Bende bıktım gerçekten (Yorum). \\
\hline Uyarı/tavsiye & $\begin{array}{l}\text { Tansiyonunuzu ölçtürün belki yükseliyor olabilir } \\
\text { (Yorum). }\end{array}$ \\
\hline Durum bildiriminde bulunma/deneyim & $\begin{array}{l}\text { Arkadaşlar herkese iyi akşamlar aranıza yeni katıldım } \\
\text { hastalıkta 6 günüm tat koku alabiliyorum ama yük- } \\
\text { sek ateş var (Yorum). }\end{array}$ \\
\hline Bilgi verme & $\begin{array}{l}\text { Bilim Kurulu Üyelerinden flaş açıklama kimse } \\
\text { güvende değil (Ana mesaj). Linkle birlikte. }\end{array}$ \\
\hline Sağlığa ilişkin soru sorma & $\begin{array}{l}\text { Hastasını yoğun bakımdan yoğun bakıma transfer } \\
\text { olan var mıdır caba nasıl bir yol izlediniz? (Ana mesaj) }\end{array}$ \\
\hline Bakıcılık hizmeti ilanı/reklam & $\begin{array}{l}\text { Covid-19 hasta bakıcısıyım refakatçi lazım olduğu } \\
\text { zaman arayabilirsiniz. Tel... (Ana mesaj). }\end{array}$ \\
\hline
\end{tabular}


